\title{
Comparative assessment of single-stage and two-stage anaerobic digestion for biogas production from high moisture municipal solid waste
}

\author{
Wattananarong Markphan ${ }^{1}$, Chonticha Mamimin ${ }^{2}$, Wantanasak Suksong ${ }^{3}$, Poonsuk Prasertsan ${ }^{2}$, Sompong 0 \\ Thong Corresp. 4,5 \\ ${ }^{1}$ Environmental Program, Faculty of Sciences and Technology, Nakhon Si Thammarat Rajabhat University, Nakhon Si Thammarat, Thailand \\ 2 Research and Development Office, Prince of Songkla University, Songkhla, Thailand \\ 3 Bioinformatics and Systems Biology Program, School of Bioresources and Technology, King Mongkut's University of Technology Thonburi, Bangkok, \\ Thailand \\ 4 Biotechnology Program, Department of Biology, Faculty of Science, Thaksin University, Phatthalung, Thailand \\ 5 Sustainable Agricultural Resources Management Program, Faculty of Technology and Community Development, Thaksin University, Phatthalung, \\ Thailand \\ Corresponding Author: Sompong O Thong \\ Email address: sompong.o@gmail.com
}

Background . Municipal solid waste (MSW) management using the incineration method generates ash and high moisture MSW as residue. Anaerobic digestion (AD) is a suitable process for treating high moisture MSW with biogas and biofertilizer production. However, the low stability of AD performance and low methane production results from high moisture MSW due to the fast acidify of carbohydrate fermentation. The effects of organic loading and incineration fly ash addition as a $\mathrm{pH}$ adjustment on methane production from high moisture MSW in the single-stage AD and two-stage AD processes were investigated.

Results. Suitable initial organic loading of the single-stage AD process was $17 \mathrm{gVS} \cdot \mathrm{L}^{-1}$ at incineration fly ash (IFA) addition of $0.5 \%$ with methane yield of $287 \mathrm{~mL} \mathrm{CH}_{4} \bullet \mathrm{g}^{-1} \mathrm{VS}$. Suitable initial organic loading of the two-stage $A D$ process was $43 \mathrm{gVS} \cdot \mathrm{L}^{-1}$ at IFA addition of $1 \%$ with hydrogen and methane yield of $47.4 \mathrm{ml}$ $\mathrm{H}_{2} \bullet \mathrm{g}^{-1}$ VS and $363 \mathrm{~mL} \mathrm{CH} \mathrm{CH}_{4} \bullet \mathrm{g}^{-1}$ VS, respectively. The highest hydrogen and methane production of $8.7 \mathrm{~m}^{3}$ $\mathrm{H}_{2} \cdot$ ton $^{-1}$ of high moisture MSW and $66.6 \mathrm{~m}^{3} \mathrm{CH}_{4} \cdot$ ton $^{-1}$ of high moisture MSW was achieved at organic loading of $43 \mathrm{gVS} \cdot \mathrm{L}^{-1}$ at IFA addition of $1 \%$ by two-stage AD process. Biogas production by the two-stage AD process enabled $18.5 \%$ higher energy recovery than single-stage AD. The $1 \%$ addition of IFA into high moisture MSW was useful for controlling $\mathrm{pH}$ of the two-stage AD process with enhanced biogas production between $87-92 \%$ when compared to without IFA addition. Electricity production and energy recovery from MSW using the coupled incineration with biogas production by two-stage AD process were 9,874 MJ.ton ${ }^{-1}$ MSW and 89\%, respectively.

Conclusions. The two-stage AD process with IFA addition for $\mathrm{pH}$ adjustment could improve biogas production from high moisture MSW, as well as reduce lag phase and enhance biodegradability efficiency. The coupled incineration process with biogas production using the two-stage AD process was suitable for the management of MSW with low area requirement, low greenhouse gas emissions, and high energy recovery. 
1 Comparative assessment of single-stage and two-stage 2 anaerobic digestion for biogas production from high 3 moisture municipal solid waste

4

5

6

7

8

Wattananarong Markphan ${ }^{1}$, Chonticha Mamimin ${ }^{2}$, Wantanasak Suksong ${ }^{3}$, Poonsuk Prasertsan ${ }^{2}$, Sompong O-Thong ${ }^{4,5}$

${ }^{1}$ Environmental Program, Faculty of Sciences and Technology, Nakhon Si Thammarat Rajabhat University, Nakhon Si Thammarat 80280, Thailand

${ }^{2}$ Research and Development Office, Prince of Songkla University, Songkhla 90112, Thailand

${ }^{3}$ Bioinformatics and Systems Biology Program, School of Bioresources and Technology, King Mongkut's University of Technology Thonburi, Bangkok 10150, Thailand

4 Biotechnology Program, Department of Biology, Faculty of Science, Thaksin University, Phatthalung 93210, Thailand

${ }^{5}$ Sustainable Agricultural Resources Management Program, Faculty of Technology and

Community Development, Thaksin University, Phatthalung 93210, Thailand

Corresponding Author:

Sompong O-Thong ${ }^{1,3}$

Pa Phayom District, Phatthalung Province 93210, Thailand.

Email address: sompong.o@tsu.ac.th

\section{Abstract}

Background. Municipal solid waste (MSW) management using the incineration method generates ash and high moisture MSW as residue. Anaerobic digestion (AD) is a suitable process for treating high moisture MSW with biogas and biofertilizer production. However, the low stability of $\mathrm{AD}$ performance and low methane production results from high moisture MSW due to the fast acidify of carbohydrate fermentation. The effects of organic loading and incineration fly ash addition as a $\mathrm{pH}$ adjustment on methane production from high moisture MSW in the single-stage $\mathrm{AD}$ and two-stage $\mathrm{AD}$ processes were investigated.

Results. Suitable initial organic loading of the single-stage AD process was $17 \mathrm{gVS} \cdot \mathrm{L}^{-1}$ at incineration fly ash (IFA) addition of $0.5 \%$ with methane yield of $287 \mathrm{~mL} \mathrm{CH}_{4} \cdot \mathrm{g}^{-1}$ VS. Suitable initial organic loading of the two-stage AD process was $43 \mathrm{gVS} \cdot \mathrm{L}^{-1}$ at IFA addition of $1 \%$ with hydrogen and methane yield of $47.4 \mathrm{ml} \mathrm{H}_{2} \cdot \mathrm{g}^{-1} \mathrm{VS}$ and $363 \mathrm{~mL} \mathrm{CH}_{4} \cdot \mathrm{g}^{-1} \mathrm{VS}$, respectively. The highest hydrogen and methane production of $8.7 \mathrm{~m}^{3} \mathrm{H}_{2} \cdot \mathrm{ton}^{-1}$ of high moisture MSW and $66.6 \mathrm{~m}^{3}$ $\mathrm{CH}_{4} \cdot \mathrm{ton}^{-1}$ of high moisture MSW was achieved at organic loading of $43 \mathrm{gVS} \cdot \mathrm{L}^{-1}$ at IFA addition 
40 of $1 \%$ by two-stage AD process. Biogas production by the two-stage AD process enabled $18.5 \%$ 41 higher energy recovery than single-stage AD. The 1\% addition of IFA into high moisture MSW 42 was useful for controlling $\mathrm{pH}$ of the two-stage AD process with enhanced biogas production 43 between $87-92 \%$ when compared to without IFA addition. Electricity production and energy 44 recovery from MSW using the coupled incineration with biogas production by two-stage AD 45 process were 9,874 $\mathrm{MJ} \cdot$ ton $^{-1} \mathrm{MSW}$ and $89 \%$, respectively.

46

47

48

49

50

51

52

53

54

55

56

57

58

59

60

61

62

63

64

65

66

67

68

69

70

71

72

73

74

75

76

77

78

79

Conclusions. The two-stage AD process with IFA addition for $\mathrm{pH}$ adjustment could improve biogas production from high moisture MSW, as well as reduce lag phase and enhance biodegradability efficiency. The coupled incineration process with biogas production using the two-stage AD process was suitable for the management of MSW with low area requirement, low greenhouse gas emissions, and high energy recovery.

\section{Introduction}

Municipal solid waste (MSW) has become a leading environmental concern due to its high quantity and the fact it contains a high amount of readily biodegradable organic waste. Landfills mostly treat MSW and require large areas, resulting in a lack of space for new landfills (Sukholthaman and Sharp, 2016). MSW incineration plays an increasingly important role in MSW management since it reduces the required area for new waste and efficiently reduces the volume of MSW (Yu et al., 2015). The incineration of MSW generates bottom ash, fly ash, and high moisture MSW as residue (Nie, 2008). The incineration of MSW generates bottom and fly ash in amounts of 250-300 and 25-50 kg·ton ${ }^{-1}$, respectively (Jakob et al., 1995). Fly ash is mainly composed of $\mathrm{Si}, \mathrm{Ca}, \mathrm{Al}$, and $\mathrm{Mg}$ (Yu et al., 2015). The incineration of MSW is suitable for low moisture MSW, but high moisture MSW can remain untreated due to low calorific value. The leftover high moisture MSW creates an unpleasant odor that creates a severe environmental problem for the community around the incineration plant. Anaerobic digestion (AD) is a suitable biological process for treating high moisture MSW with biogas production and a semi-solid digestate as a fertilizer (Abdeshahian et al., 2016). Borowski (2015) reported that biogas yield from the co-digestion of MSW with sewage sludge reached 0.309 to $0.315 \mathrm{~m}^{3} \mathrm{~kg}^{-1} \mathrm{VS}$ under mesophilic conditions. However, the AD process indicates some limitations for the organic fraction of MSW with low stability, fast acidification due to high carbohydrate content, low methane production rate, and low VS degradation efficiency (Pavi et al., 2017).

The single-stage AD process is commonly applied for biogas production from high moisture MSW and faced with high volatile fatty acids accumulation and inhibition. A previous report from Michele et al. (2015) found that biogas production from the organic fraction of MSW causes reactor instability performance, as indicated by $\mathrm{H}_{2}$ concentrations of $8 \%$ in biogas and low $\mathrm{pH}$ (6.5). The low methane yield of $180 \mathrm{~mL} \cdot \mathrm{g}^{-1} \mathrm{VS}$ is observed in the AD of organic fraction of MSW containing high amounts of food waste (Forster-Carneiro et al., 2007). The instability of the AD systems feeding with the organic fraction of MSW is mostly influenced by VFAs accumulation, which inhibits methanogenic activity (Pavi et al., 2017). Adding ash to organic 
80

81

82

83

84

85

86

87

88

89

90

91

92

93

94

95

96

97

98

99

100

101

102

103

104

105

106

107

108

109

110

111

112

113

114

115

116

117

118

119

waste before being fed into the $\mathrm{AD}$ process improves the stability and reduces VFA accumulation. Ash releases alkali metals that contribute to increasing $\mathrm{pH}$ and buffer capacity in AD systems (Lo, 2005). The ash addition can control the $\mathrm{pH}$ of AD systems fed with the organic fraction of MSW at a suitable $\mathrm{pH}$ range (7.0-8.5) with enhanced VS degradation and methane production (Banks and Lo, 2003). The metals in the ash could act as co-enzymes during the AD process and enhance microbial growth. The improvement of biogas production by ash addition was also reported by Mamimin et al. (2019), who found that the addition of 5\% oil palm fiber ash into palm oil mill effluent could improve biohythane production using the two-stage AD process. The two-stage AD process using the separation of acidogenic bacteria and methanogenic archaea enhance biogas production, substrate degradation efficiency, and the stability of the AD process (Demirel and Yenigun, 2002). The two-stage AD process increases methane production from olive mill waste by $10 \%$ when compared with the single-stage AD process (Rincón et al., 2009). The two-stage AD process has a higher reactor operation stability at high organic loading rates than the single-stage AD process. However, there are still few commercial applications for a two-stage AD digester. Therefore, this work aimed to evaluate methane production from high moisture MSW in both single-stage AD and two-stage AD processes. The effects of organic loading and incineration fly ash addition as a $\mathrm{pH}$ adjustment on biogas production of single-stage $\mathrm{AD}$ and two-stage $\mathrm{AD}$ processes were investigated.

\section{Materials \& Methods}

\section{Substrates and Inoculum}

MSW was collected from landfill disposal sites located in Nakhon Si Thammarat Province, Thailand, from December 16 to 25,2016 . Roughly $200 \mathrm{~kg}$ of MSW was separated as low moisture MSW ( $<60 \%)$ and high moisture MSW ( $>60 \%)$ using the quartering method (Armijo de Vega et al., 2008). Incineration fly ash (IFA) was collected from the municipal solid waste incinerator at PJT Technology Co., Ltd., Phuket Province, Thailand. The high moisture MSW and IFA were dried at $95^{\circ} \mathrm{C}$ until the moisture content was less than $10 \%(w / w)$. Dry MSW was milled with a hammer mill to $5 \mathrm{~mm}$ before being used as a substrate in the AD process. High moisture MSW was analyzed for $\mathrm{pH}$, total solids (TS), volatile solids (VS), ash, protein, carbohydrates, and lipids according to APHA (2012). The IFA was analyzed for $\mathrm{MgO}$, $\mathrm{Al}_{2} \mathrm{O}_{3}, \mathrm{SiO}_{2}, \mathrm{~K}_{2} \mathrm{O}, \mathrm{CaO}, \mathrm{TiO}_{2}, \mathrm{Fe}_{2} \mathrm{O}_{3}, \mathrm{Rb}, \mathrm{SrO}, \mathrm{Cl}, \mathrm{Na}_{2} \mathrm{O}, \mathrm{P}_{2} \mathrm{O}_{5}$ and $\mathrm{SO}_{3}$ content using an X-ray fluorescence spectrometer (Tan et al., 2002). The theoretical methane yield of high moisture MSW was calculated based on a modified Buswell equation 1 and 2 from the CHON elemental composition (Buswell and Mueller, 1952). Hydrogen-producing sludge for the first-stage was collected from a hydrogen production reactor feeding with palm oil mill effluent. The sludge was cultivated on a $2 \mathrm{~g} \cdot \mathrm{L}^{-1}$ sucrose medium for enhancing hydrogen-producing bacteria $(O$-Thong et al., 2009). The enriched sludge with volatile suspended solids of $6.0 \mathrm{~g} \cdot \mathrm{L}^{-1}$ was used as inoculum for the first stage (Mamimin et al., 2015). Methane production sludge was collected from biogas digester feeding with palm oil mill effluent. The anaerobic sludge was incubated at $35^{\circ} \mathrm{C}$ for 10 days to remove the remaining organic materials. The sludge with volatile solids (VS) of $80 \mathrm{~g} \cdot \mathrm{L}^{-1}$ 
120

121

122

123

124

125

126

127

128

129

130

131

132

133

134

135

136

137

138

139

140

141

142

143

144

145

146

147

148

149

150

151

152

153

154

155

156

157

158

was used as inoculum for second-stage and single-stage methane production (O-Thong et al., 2016). The composition of hydrogen and methane inoculum is shown in Table 1.

$\mathrm{C}_{\mathrm{a}} \mathrm{H}_{\mathrm{b}} \mathrm{O}_{\mathrm{c}} \mathrm{N}_{\mathrm{d}}+\left(\frac{4 \mathrm{a}-\mathrm{b}-2 \mathrm{c}+3 \mathrm{~d}}{4}\right) \mathrm{H}_{2} \mathrm{O} \rightarrow\left(\frac{4 \mathrm{a}+\mathrm{b}-2 \mathrm{c}-3 \mathrm{~d}}{8}\right) \mathrm{CH}_{4}+\mathrm{a}-\left(\frac{4 \mathrm{a}+\mathrm{b}-2 \mathrm{c}-3 \mathrm{~d}}{8}\right) \mathrm{CO}_{2}+\mathrm{d} \mathrm{NH}$

$\mathrm{C}_{29} \mathrm{H}_{48} \mathrm{O}_{14} \mathrm{~N}+11 \mathrm{H}_{2} \mathrm{O} \rightarrow 17 \mathrm{CH}_{4}+12 \mathrm{CO}_{2}+\mathrm{NH}_{3}$

\section{Biogas production from high moisture MSW by single-stage AD}

Biogas production from high moisture MSW using single-stage AD was investigated at a working volume of $200 \mathrm{~mL}$ in a $1 \mathrm{~L}$ reactor under mesophilic conditions (Figure 1). The high moisture MSW at initial VS loading of 9, 17, 26, 35, and $43 \mathrm{~g}-\mathrm{VS} \cdot \mathrm{L}^{-1}$ was mixed with methaneproducing inoculum at a substrate to inoculum ratio (S:I) of 2:1 based on VS basis (Angelidaki et al., 2009). The $0.5 \%$ and $1 \%$ IFA were added into the mixtures as initial $\mathrm{pH}$ adjustment to $7.2-$ 7.5. The mixtures were purged with nitrogen gas at a flow rate of $500 \mathrm{~mL} \cdot \mathrm{min}^{-1}$ for 3 min to remove the oxygen in the reactor headspace. The reactors were closed with a rubber stopper and incubated under mesophilic conditions $\left(35^{\circ} \mathrm{C}\right)$ for 45 days. All treatments were done in triplicate. The biogas volume and gas composition were monitored daily using the water displacement method and gas chromatography, respectively.

\section{Biogas production from high moisture MSW by two-stage AD}

The biogas production from high moisture MSW using the two-stage AD process was assayed as previously described by Mamimin et al. (2016). The reactor size of $1 \mathrm{~L}$ with a working volume of $200 \mathrm{~mL}$ was used for the first stage and $600 \mathrm{~mL}$ was used for the second stage (Fig 1). Different initial VS loading of high moisture MSW at 9, 17, 26, 35, and 43 g-VS $\cdot \mathrm{L}^{-1}$ was mixed with hydrogen-producing sludge at S:I of 20:1 based on VS basis for the first stage (Mamimin et al., 2019). The 0.5 and $1.0 \%$ IFA was added into the mixtures for initial $\mathrm{pH}$ adjustment to 5.5-6. The mixture was added to the reactors and closed with a rubber stopper. The reactors were incubated under mesophilic conditions $\left(35^{\circ} \mathrm{C}\right)$ for 15 days. After 15 days, the reactors were opened in a nitrogen environment and introduced methane-producing inoculum at $\mathrm{S}$ :I ratio of 2:1 based on the VS basis for the second stage AD process. The reactors were closed with a rubber stopper and continue incubated at mesophilic conditions $\left(35^{\circ} \mathrm{C}\right)$ for 45 days. All of the treatments were done in triplicate. The volume of biogas was measured by the water displacement method. The gas composition was determined by gas chromatography. The biogas was taken once every day in the first stage for hydrogen gas analysis. The biogas was taken from the second stage every day in the first week and then every 2 days thereafter for methane gas analysis. The microbial community responsible for two-stage AD was analyzed by polymerase chain reaction-denaturing gradient gel electrophoresis (PCR-DGGE) techniques.

\section{Microbial community analysis}


159

160

161

162

163

164

165

166

167

168

169

170

171

172

173

174

175

176

177

178

179

180

181

182

183

184

185

186

187

188

189

190

191

192

193

194

195

196

197

Sludge samples from an optimum condition for biogas production by two-stage AD processes were taken for PCR-DGGE analysis. The genomic DNA of sludge samples was extracted using a method previously described by Kuske et al. (1998). The DNA quality was checked by agarose gel electrophoresis and used as a template for the two-step polymerase chain reaction (PCR). The first PCR for the 16S rRNA of the archaea population was amplified by primer Arch21f (5' TTCCGGTTGATCCYGCCGGA 3') and Arch958r (5' YCCGGCGTTGAMTCCAATT 3'). The first PCR for the 16S rRNA of the bacteria population was amplified by primer 1492r (5' GAAAGGAGGTGATCCAGCC 3') and 27f (5' GAGTTTGATCCTTGGCTCAG 3'). PCR amplification was conducted in an automated thermal cycler with pre-denaturation at $95{ }^{\circ} \mathrm{C}$ for 5 min followed by 25 cycles of denaturation at $95{ }^{\circ} \mathrm{C}$ for $30 \mathrm{~s}$, annealing at $52{ }^{\circ} \mathrm{C}$ for $40 \mathrm{~s}$, elongation at $72{ }^{\circ} \mathrm{C}$ for $90 \mathrm{~s}$, and post-elongation at $72{ }^{\circ} \mathrm{C}$ for $5 \mathrm{~min}$. The reactions were subsequently cooled to $4{ }^{\circ} \mathrm{C}$ (O-Thong et al., 2009). The second PCR was amplified from the amplicons of the first PCR as a DNA template with primer Arch519r (5' TTACCGCGGCKGCTG 3' with 40 bp GC clamp) and Arch340f (5' CCTACGGGGYGCASCAG 3') for archaea population. The second PCR of bacteria population was amplified with primer 518r (5' ATTACCGAGCTGCTGG 3' with 40 bp GC-clamp) and $357 f$ (5' CCTACGGGAGGCAGCAG 3'). PCR products were analyzed on agarose gel electrophoresis before DGGE analysis. The amplicons from the second PCR were used for DGGE analysis, as previously described by Prasertsan et al. (2009). The DGGE bands were excised from the gel and re-amplified under similar conditions as the second PCR. The PCR product was purified and sequenced by Macrogen Inc. (Seoul, Korea). The identification of 16S rRNA gene sequences from DGGE bands was carried out by BLAST database searches in GenBank (Tatusova et al., 2016).

\section{Analytical methods}

The composition of high moisture MSW was analyzed for $\mathrm{pH}, \mathrm{TS}$, VS, protein, carbohydrates, and lipids according to standard methods (APHA, 2012). The chemical composition of high moisture MSW with regards to the elements $\mathrm{C}, \mathrm{H}, \mathrm{O}$, and $\mathrm{N}$ was analyzed according to Lesteur et al. (2010). The total energy of MSW was analyzed using a bomb calorimeter (GE-5055 Compensated Jacket Calorimeter, Parr, Illinois, USA). Biogas compositions were analyzed by gas chromatography (GC-8A Shimadzu, Kyoto, Japan) equipped with thermal conductivity detectors (TCD) and fitted with a $2.0 \mathrm{~m}$ packed column (Shin-Carbon ST 100/120 Restek). Volatile fatty acids (VFA) were analyzed by gas chromatography (GC-17A, Shimadzu, Kyoto, Japan) equipped with a flame ionization detector (FID) and Stabilwax-DA column (dimensions $30 \mathrm{~m}$ x0.32 $\mathrm{mm} \times 0.25 \mathrm{~mm}$ ). The cumulative methane yield from a singlestage and two-stage $\mathrm{AD}$ process was fitted for hydrolysis rate constant $\left(k_{h}\right)$, as in equation 3 below.

$$
\ln \frac{B_{\infty-B}}{B_{\infty}}=-k_{h} t
$$


198

199

200

201

202

203

204

205

206

207

208

209

210

211

212

213

214

215

216

217

218

219

220

221

222

223

224

225

226

227

228

229

230

231

232

233

234

235

236

Where $B_{\infty}$ is the ultimate biogas yield, and $B$ is the biogas yield at a given time $(t)$. The digestion kinetics of high moisture MSW in the single-stage and two-stage AD system were evaluated by the modified Gompertz equation. The lag phase $(\mathrm{d})$ and biogas production rate $\left(\mathrm{mL} \cdot \mathrm{gVS}^{-1} \cdot \mathrm{d}^{-1}\right)$ were also estimated from the modified Gompertz equation.

$B(t)=P_{\max } \times \exp \left(-\exp \left(\frac{R_{\max } \times e}{P_{\max }} \times(\lambda-t)+1\right)\right), t \geq 0$

Where $B(t)$ is the specific hydrogen and methane yield of high moisture MSW at a given time (mL $\left.\cdot \mathrm{g}^{-1} \mathrm{VS}\right) . P_{\max }$ is the maximum hydrogen and methane potential $\left(\mathrm{mL} \cdot \mathrm{g}^{-1} \mathrm{VS}\right) . t$ is the digestion time (d). $R$ is the maximum hydrogen and methane production rate $\left(\mathrm{mL} \cdot \mathrm{g}^{-1} \mathrm{VS} \cdot \mathrm{d}^{-1}\right) . \lambda$ is the lagtimes. $e$ is the exponential of 1 , which is 2.71828 (Zhen et al., 2016).

\section{Results}

\section{High moisture MSW and IFA composition}

High moisture MSW from a landfill site in Nakhon Si Thammarat, Thailand was mainly composed of food waste, green waste, fruit waste, and vegetable waste. The MSW contained $53.6 \%$ high moisture waste and $46.4 \%$ low moisture waste. High moisture MSW had TS, VS, ash, and moisture of $26.36 \%, 18.34 \%, 8.02 \%$, and $65.62 \%$, respectively (Table 2). The high moisture MSW contained high carbohydrate and protein content. The protein, carbohydrates, lipids in the high moisture MSW amounted to $20.4 \%, 38.6 \%$, and $11.0 \%$ of TS, respectively. Incineration fly ash (IFA) was mainly composed of $\mathrm{CaO}, \mathrm{Cl}, \mathrm{Na}_{2} \mathrm{O}, \mathrm{K}_{2} \mathrm{O}$, and $\mathrm{SO}_{3}$ at 39.6, 22.1, $8.35,4.95$, and $3.22 \%$ of TS, respectively (Table 3 ).

\section{Biogas production from high moisture MSW by the single-stage AD process}

The theoretical methane yield of high moisture MSW was $576 \mathrm{~mL} \cdot \mathrm{g}^{-1} \mathrm{VS}$, while real biogas production using the single-stage AD process was $268-287 \mathrm{~mL}-\mathrm{CH}_{4} \cdot \mathrm{g}^{-1} \mathrm{VS}$. A maximum methane yield of $287 \mathrm{~mL}-\mathrm{CH}_{4} \cdot \mathrm{g}^{-1} \mathrm{VS}$ was achieved at an initial VS loading of $17 \mathrm{~g}-\mathrm{VS} \cdot \mathrm{L}^{-1}$ with IFA addition of $0.5 \%(\mathrm{w} / \mathrm{v})$. The methane yields at initial VS loading of $9,17,26,35,43 \mathrm{gVS} \cdot \mathrm{L}^{-1}$ with $0.5 \%(\mathrm{w} / \mathrm{v})$ IFA addition were $220,287,179,10.5$, and $5.08 \mathrm{~mL} \mathrm{CH}_{4} \cdot \mathrm{g}^{-1} \mathrm{VS}$, respectively (Fig. 2). The methane yields at initial VS loading of 9, 17, 26, 35, $43 \mathrm{gVS} \cdot \mathrm{L}^{-1}$ with $1 \%(\mathrm{w} / \mathrm{v})$ IFA addition were $238,268,218,16.4$, and $5.35 \mathrm{~mL} \mathrm{CH}_{4} \cdot \mathrm{g}^{-1} \mathrm{VS}$, respectively. The results indicated that methane yield at initial VS loading of $9-17 \mathrm{gVS} \cdot \mathrm{L}^{-1}$ at both IFA addition was significantly $(\mathrm{p}<0.05)$ higher than the initial VS loading of $>17 \mathrm{gVS} \cdot \mathrm{L}^{-1}$. The single-stage AD process could completely degrade high moisture MSW at initial loading of $9-26 \mathrm{gVS} \cdot \mathrm{L}^{-1}$ at both IFA addition. The VFAs concentration of the single-stage AD process at initial VS loading of $9-26 \mathrm{gVS} \cdot \mathrm{L}^{-1}$ at IFA addition of $0.5 \%$ and $1 \%(\mathrm{w} / \mathrm{v})$ were $178-267$ and $186-240 \mathrm{mg} \cdot \mathrm{L}^{-1}$, respectively (Table 4). The initial VS loading of $>26 \mathrm{gVS} \cdot \mathrm{L}^{-1}$ had low methane yield $\left(5.08-16.4 \mathrm{~mL}-\mathrm{CH}_{4} \cdot \mathrm{g}^{-1} \mathrm{VS}\right)$ and high VFA accumulation (1.2-2.2 $\left.\mathrm{g} \cdot \mathrm{L}^{-1}\right)$ at both IFA addition. The initial VS loading of $>26$

Peer] reviewing PDF | (2019:09:41176:2:1:NEW 11 Jul 2020) 
$237 \mathrm{gVS} \cdot \mathrm{L}^{-1}$ had high acetic acid, propionic acid, and butyric acid in the AD system. The acetic acid, 238 propionic acid, and butyric acid concentration in the AD system at initial VS loading of $>26$ $239 \mathrm{gVS} \cdot \mathrm{L}^{-1}$ were $553-979,105-187,541-1026 \mathrm{mg} \cdot \mathrm{L}^{-1}$, respectively (Table 5 ). The total alkalinity of 240 the single-stage AD process at all initial VS loading at IFA addition of 0.5 and $1 \%(\mathrm{w} / \mathrm{v})$ was $2412,600-4,600$ and 2,450-3,500 $\mathrm{mg}-\mathrm{CaCO}_{3} \cdot \mathrm{L}^{-1}$, respectively. The initial VS loading of $>26 \mathrm{gVS} \cdot \mathrm{L}^{-}$

2421 at both IFA addition had a VFA to alkalinity ratio higher than 0.3 , indicating the imbalance of 243 the AD process for biogas production. High moisture MSW without IFA addition had no 244 methane production due to high VFAs accumulation $\left(1,235 \mathrm{mg} \cdot \mathrm{L}^{-1}\right)$ and low alkalinity $(508 \mathrm{mg}-$ $245 \mathrm{CaCO}_{3} \cdot \mathrm{L}^{-1}$ ), leading to low $\mathrm{pH}$ and an inhibited $\mathrm{AD}$ process. The high methane production rate 246 of 14.2-15.3 was also achieved at an initial VS loading of $17 \mathrm{gVS} \cdot \mathrm{L}^{-1}$. The lag phase of the 247 single-stage AD process was 6-11 days at an initial VS loading of $17 \mathrm{gVS} \cdot \mathrm{L}^{-1}$; increasing the VS loading extended the lag phase. Suitable initial organic loading of the single-stage AD process 249

250 was $17 \mathrm{gVS} \cdot \mathrm{L}^{-1}$ at IFA addition of $0.5 \%$ with methane yield of $287 \mathrm{~mL} \mathrm{CH}_{4} \cdot \mathrm{g}^{-1} \mathrm{VS}$. Maximum methane production of $48.7 \mathrm{~m}^{3} \mathrm{CH}_{4} \cdot$ ton $^{-1}$ high moisture MSW was achieved at initial VS loading

251

252

253

254

255

256

257

258

259

260

261

262

263

264

265

266

267

268

269

270

271

272

273

274

275

276

of $17 \mathrm{gVS} \cdot \mathrm{L}^{-1}$ at IFA addition of $0.5 \%$. Maximum biodegradation efficiency of $50 \%$ and $47 \%$ was achieved at initial VS loading of $17 \mathrm{gVS} \cdot \mathrm{L}^{-1}$ with IFA addition of 0.5 and $1 \%(\mathrm{w} / \mathrm{v})$, respectively. Methane production, methane yield, and biodegradation efficiency of high moisture MSW in the single-stage AD process at IFA addition of $0.5 \%(\mathrm{w} / \mathrm{v})$ were not significantly different $(\mathrm{p}>0.05)$ with IFA addition of $1 \%(\mathrm{w} / \mathrm{v})$. The methane production and methane yield of high moisture MSW with IFA addition were significantly $(\mathrm{p}<0.05)$ higher than without IFA addition.

\section{Hydrogen and methane production from high moisture MSW by the two-stage AD process}

Biogas production and process performance of high moisture MSW using the two-stage $\mathrm{AD}$ process at different initial VS loading and IFA addition for $\mathrm{pH}$ adjustment are shown in Table 6. Between $80-90 \%$ of hydrogen was produced within 4-6 days in all experiments with IFA addition. Hydrogen content in the biogas ranged from $30-40 \%$. The lag phase for hydrogen production of high moisture MSW in the first stage was 0.4-1.0 d. The hydrolysis rate of high moisture MSW in the first stage was $0.22-0.87 \mathrm{~d}^{-1}$. The biodegradation of high moisture MSW in the first stage AD process was $9-10 \%$. The hydrogen yields of first stage AD at initial VS loading of $9,17,26,35,43 \mathrm{gVS} \cdot \mathrm{L}^{-1}$ with $0.5 \%$ IFA addition were $40.8,47.6,46.4,43.3$, and 42.5 $\mathrm{mL} \mathrm{H}_{2} \cdot \mathrm{g}^{-1} \mathrm{VS}$, respectively (Fig. 3a). The hydrogen yields at initial VS loading of 9, 17, 26, 35, $43 \mathrm{gVS} \cdot \mathrm{L}^{-1}$ with $1 \%$ IFA addition were $16.4,41.3,43.0,36.1$, and $47.4 \mathrm{~mL} \mathrm{H}_{2} \cdot \mathrm{g}^{-1} \mathrm{VS}$, respectively (Fig. 3c). The hydrogen yield of high moisture MSW without IFA addition was 8.05 $\mathrm{mL} \mathrm{H}_{2} \cdot \mathrm{g}^{-1}$ VS with a VFA concentration of $3,328 \mathrm{mg} \cdot \mathrm{L}^{-1}$. The IFA addition $(0.5-1 \% \mathrm{w} / \mathrm{v})$ increased hydrogen yield 2-6 times compared to high moisture MSW alone. The hydrogen yields of all initial VS loading at both IFA addition were similar, while the hydrogen production rate at low initial VS loading of 9-17 $\mathrm{gVS} \cdot \mathrm{L}^{-1}\left(7-16.2 \mathrm{~mL} \mathrm{H} \cdot \mathrm{g}^{-1} \mathrm{VS} \cdot \mathrm{d}^{-1}\right)$ was significantly $(\mathrm{p}<0.05)$ higher than high initial VS loading of 26-43 $\mathrm{gVS} \cdot \mathrm{L}^{-1}\left(8-11 \mathrm{~mL} \mathrm{H}_{2} \cdot \mathrm{g}^{-1} \mathrm{VS}^{-1} \mathrm{~d}^{-1}\right)$ (Table 6). The high VFAs concentration of $1,185-2,066 \mathrm{mg} \cdot \mathrm{L}^{-1}$ was observed in hydrogen effluent at all VS loading

Peer) reviewing PDF | (2019:09:41176:2:1:NEW 11 Jul 2020) 
277 with 0.5 and $1 \%(\mathrm{w} / \mathrm{v})$ IFA addition. The total alkalinity of high moisture MSW with IFA 278 addition ranged from $900-1,300 \mathrm{mg}-\mathrm{CaCO}_{3} \cdot \mathrm{L}^{-1}$, while the high moisture MSW without IFA 279 addition had low total alkalinity of $315 \mathrm{mg}-\mathrm{CaCO}_{3} \cdot \mathrm{L}^{-1}$. Low buffer capacity was observed in the 280 AD of high moisture MSW without IFA addition. The addition of ash into high moisture MSW

281

282

283

284

285

286

287

288

289

290

291

292

293

294

295

296

297

298

299

300

301

302

303

304

305

306

307

308

309

310

311

312

313

314

315

316 supports buffer capacity and prevents inhibition from low $\mathrm{pH}$. The maximum hydrogen production of high moisture MSW with IFA addition was $8.7 \mathrm{~m}^{3} \mathrm{H}_{2} \cdot$ tons $^{-1}$ of high moisture MSW, while the hydrogen production of high moisture MSW without IFA addition was $1.39 \mathrm{~m}^{3}$ $\mathrm{H}_{2} \cdot$ tons $^{-1}$ of high moisture MSW. The IFA addition $(0.5-1 \% \mathrm{w} / \mathrm{v})$ improves hydrogen production from high moisture MSW by $82 \%$ when compared with hydrogen production from high moisture MSW without IFA addition.

The homogenized hydrogen effluent from the first stage was used as a substrate for methane production in the second stage. The methane yields of the second stage at initial VS loading of 9, 17, 26, 35, $43 \mathrm{gVS} \cdot \mathrm{L}^{-1}$ with $0.5 \%$ IFA addition were 399, 396, 400, 362, and 319 $\mathrm{mL} \mathrm{CH}_{4} \cdot \mathrm{g}^{-1} \mathrm{VS}$, respectively (Fig. 3b). The methane yields at initial VS loading of 9, 17, 26, 35, and $43 \mathrm{gVS} \cdot \mathrm{L}^{-1}$ with $1 \%$ IFA addition were $348,369,375,341$, and $363 \mathrm{~mL} \mathrm{CH} \mathrm{CH}_{4} \cdot \mathrm{g}^{-1} \mathrm{VS}$, respectively (Fig. 3d). Methane yield of high moisture MSW without IFA addition in the second stage was $315 \mathrm{~mL} \mathrm{CH}_{4} \cdot \mathrm{g}^{-1} \mathrm{VS}$. The IFA addition $(0.5$ and $1 \% \mathrm{w} / \mathrm{v})$ improved methane yield $15-$ $20 \%$ from high moisture MSW via the two-stage AD process. The lag phase of methane production in the two-stage AD process (0.85-1.91 days) was shorter than the single-stage AD process (6-30 days) (Table 6). IFA addition to high moisture MSW effectively increased biogas production in the second stage. Stable alkalinity, high biodegradation efficiency, low VFAs accumulation, and higher methane production were achieved in the two-stage AD process. The VFAs and total alkalinity after methane production ranged between $78-276 \mathrm{mg} \cdot \mathrm{L}^{-1}$ and 3,050 $3,700 \mathrm{mg}-\mathrm{CaCO}_{3} \cdot \mathrm{L}^{-1}$, respectively (Table 7). Suitable initial organic loading of the two-stage AD process was $43 \mathrm{gVS} \cdot \mathrm{L}^{-1}$ at IFA addition of $1 \%$ with methane yield of $363 \mathrm{~mL} \mathrm{CH} \mathrm{CH}^{-1} \mathrm{VS}$. Maximum methane production of $66.6 \mathrm{~m}^{3} \mathrm{CH}_{4} \cdot$ tons $^{-1}$ of high moisture MSW was achieved from high moisture MSW at the initial VS loading of $43 \mathrm{gVS} \cdot \mathrm{L}^{-1}$ with $1.0 \%$ IFA addition corresponded to maximum biodegradation efficiency of $63.1 \%$. The highest hydrogen and methane production of $8.7 \mathrm{~m}^{3} \mathrm{H}_{2} \cdot \mathrm{ton}^{-1}$ high moisture MSW and $66.6 \mathrm{~m}^{3} \mathrm{CH}_{4} \cdot \mathrm{ton}^{-1}$ high moisture MSW was achieved at organic loading of $43 \mathrm{gVS} \cdot \mathrm{L}^{-1}$ at IFA addition of $1 \%$ by the two-stage $\mathrm{AD}$ process. Biogas production by the two-stage AD process showed $18.5 \%$ higher energy recovery than the single-stage AD process. The addition of IFA at $1 \%$ into high moisture MSW was useful for controlling $\mathrm{pH}$ for the two-stage AD process with enhanced biogas production between $87-92 \%$ when compared to without IFA addition.

\section{Microbial community of the two-stage AD process}

Bacteria and archaea community structures of the two-stage AD process at initial VS loading of $43 \mathrm{gVS} \cdot \mathrm{L}^{-1}$ with the IFA addition of $1 \%$ are shown in Fig. 4 . The bacterial community in the first stage for hydrogen production was composed of Clostridium sp., Sphingobacterium sp., Gramella sp., Eubacterium sp., and Lactobacillus sp. No archaea were found in the first 
317 stage. Clostridium sp. and Sphingobacterium sp. were dominated in the first stage and involved 318 in hydrogen production from high moisture MSW. The bacterial community in the second stage 319 for methane production was composed of Clostridium sp., Sulfurihydrogenibium sp., Gramella 320 sp., Lutaonella sp., Sphingobacterium sp., Cellulophaga sp., and Flavobacterium sp. The 321 archaeal community of the second-stage was dominated by hydrogenotrophic and acetoclastic 322 methanogen. The archaea community of the second stage was composed of Methanobacterium 323 sp., Methanocaldoccus sp., and Methanothermus sp. The two-stage AD process was dominated 324 by Clostridium sp., Sphingobacterium sp., Methanobacterium sp., and Methanothermus sp.,

325

326

327

328

329

330

331

332

333

334

335

336

337

338

339

340

341

342

343

344

345

346

347

348

349

350

351

352

353

354

355

356 which were responsible for hydrogen and methane production.

\section{Energy recovery}

Energy recovery from MSW using the coupled incineration process with biogas production by the two-stage AD process is shown in Fig 5. Municipal solid waste management by landfills has no energy recovery and high greenhouse gas emissions $\left(1360 \mathrm{kgCO}\right.$-eq.ton ${ }^{-1}$ MSW). The greenhouse gas emissions from MSW management by landfills comprise mainly methane emissions (64.65 $\mathrm{kg} \mathrm{CH} \mathrm{CH}_{4}$ ton $^{-1}$ ), which corresponds to $1360 \mathrm{~kg} \mathrm{CO}_{2}$-eq of $\mathrm{GHG}$ emissions. The management of MSW by incineration can recover energy from low moisture

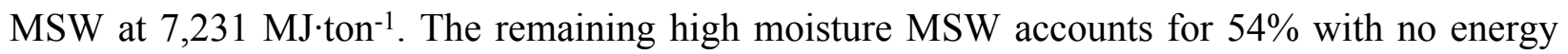
recovery and high greenhouse gas emissions $\left(762 \mathrm{kgCO}_{2}\right.$-eq.ton $\left.{ }^{-1} \mathrm{MSW}\right)$. The management of MSW by incineration is better than landfilling in terms of energy recovery and greenhouse gas emissions. Energy recovery from MSW via the incineration process remains at $66 \%$. The coupled incineration process with biogas production using the two-stage AD process for MSW management can significantly increase energy recovery by up to $89 \%$. Energy production from high moisture MSW in the form of biogas via a two-stage AD process with IFA addition was 2,553 MJ $\mathrm{ton}^{-1}$. Energy production from the coupled incineration process with biogas production

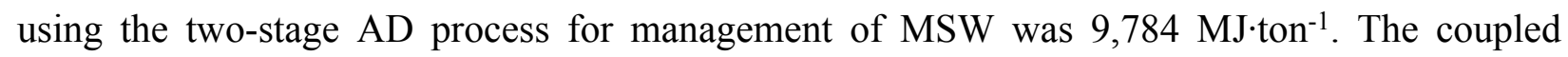
incineration process with biogas production using the two-stage AD process for management of both low moisture and high moisture MSW could reduce landfill area as well as the emission of greenhouse gases (GHG). High moisture MSW treated via the two-stage AD process could decrease GHG emissions by $762 \mathrm{~kg} \mathrm{CO}$-eq·ton ${ }^{-1} \mathrm{MSW}$. Therefore, the coupled incineration process with biogas production using the two-stage AD process could provide a solution for reducing GHG and boost efforts to achieve sustainable development for MSW management.

\section{Discussion}

High biogas production from high moisture MSW with IFA addition by the single-stage AD process was achieved at low VS loading $\left(9-17 \mathrm{gVS} \cdot \mathrm{L}^{-1}\right)$ with low VFAs accumulation $(<300$ $\left.\mathrm{mg} \cdot \mathrm{L}^{-1}\right)$. The excellent AD performance of organic fraction MSW was obtained at low VS loading (Yan et al., 2019). Mattioli et al. (2017) also found that optimum VS loading of organic fraction MSW was $29 \mathrm{gVS} \cdot \mathrm{L}^{-1}$ with maximum methane yield of $270 \mathrm{ml}-\mathrm{CH}_{4} \cdot \mathrm{g}^{-1} \mathrm{VS}$ by a singlestage AD reactor. The alkalinity was in line with previously reported $3,000-5,000 \mathrm{mg}-\mathrm{CaCO}_{3} \cdot \mathrm{L}^{-1}$ 
357

358

359

360

361

362

363

364

365

366

367

368

369

370

371

372

373

374

375

376

377

378

379

380

381

382

383

384

385

386

387

388

389

390

391

392

393

394

395

396

(Angelidaki et al., 2009). The VS loading of $>26 \mathrm{gVS} \cdot \mathrm{L}^{-1}$ for both IFA addition $(0.5 \%$ and $1 \%)$ had a VFA to alkalinity ratio higher than 0.3 , indicating the imbalance of the AD process for biogas production (Khanal, 2008). The volatile fatty acids/alkalinity ratio should be maintained at 0.10-0.30 to avoid acidification of the AD process (Barampouti et al., 2005). The low buffered and fast acidified high moisture MSW resulted in an imbalance of the single-stage AD process due to the quick change of $\mathrm{pH}$ under the high VS loading (Zhang et al., 2012). High moisture MSW with IFA addition for $\mathrm{pH}$ adjustment could improve the self-buffering capacity to meet the demands of microbial growth (Zhang et al., 2016). The results were confirmed by Podmirseg et al. (2013), who found that the loading of $0.5 \mathrm{~g}$ ash $\cdot \mathrm{g}^{-1} \mathrm{TS}$ could enhance biogas production as well as improve the hydrolysis rate. The IFA addition of $0.5-1 \% \mathrm{w} / \mathrm{v}$ into high moisture MSW could improve hydrogen yield (2-6 times) and methane yield (0.2-0.5 times) for the two-stage AD process. High moisture MSW contains high carbohydrates (including rice), making it a suitable substrate for hydrogen production and the immediate generation of hydrogen after inoculation (Dong et al., 2009). Mamimin et al. (2019) reported that ash addition into palm oil mill effluent enhanced hydrogen production and hydrogen yield by the two-stage AD process. Microelements in ash are vital for the enzymes involved in the biological hydrogen production pathway, resulting in the high degradation efficiency of substrates and high hydrogen yield (Mamimin et al., 2019; Thanh et al., 2016). The trace metals in IFA were possibly metabolized as micronutrients in the first stage of hydrolytic and acidogenic bacteria (Lo, 2005).

Hydrolytic and acidogenic bacteria were dominated in the first stage. Clostridium sp., Sphingobacterium sp., Eubacterium sp., and Lactobacillus sp. are very useful in the degradation of lipids, carbohydrates, and proteins (Martin-González et al., 2011). The main compositions of high moisture MSW were carbohydrates, proteins, and lipids. Yuan et al. (2012) found that Clostridium sp. could utilize various carbon sources such as cellobiose, glucose, xylose, and sucrose with a volatile fatty acid, carbon dioxide, and hydrogen production. The archaeal community of the second-stage was dominated by hydrogenotrophic and acetoclastic methanogen. Methanobacterium sp. can utilize $\mathrm{H}_{2} / \mathrm{CO}_{2}$ and formate as substrates for methane production (Yang et al., 2015). Luo et al. (2015) reported that biochar could enrich Methanobacterium sp. when added to the AD system. Methanobacterium sp. was dominated in the AD system with biochar addition. IFA addition into high moisture MSW enhanced biogas production, the diversity of bacteria, and the diversity of archaea by acting as co-enzymes and buffer capacity during the AD process. The populations of Methanosaeta sp., Methanobacteriales, Methanobacterium sp., Methanococcales were increased by $208 \%, 133 \%$, $50 \%$, and $144 \%$, respectively, after proper $\mathrm{pH}$ adjustment of the $\mathrm{AD}$ systems (Zahedi et al., 2016).

\section{Conclusions}

The two-stage AD process enhances methane production and biodegradation efficiency with a short lag phase from high moisture MSW. Hydrogen and methane production of $7.9 \mathrm{~m}^{3}$ 
397

398

399

400

401

402

403

404

405

406

407

408

409

410

411

412

413

414

415

416

417

418

419

420

421

422

423

424

425

426

427

428

429

430

431

432

433

434

435

$\mathrm{H}_{2} \cdot$ ton $^{-1}$ high moisture MSW and $68.1 \mathrm{~m}^{3} \mathrm{CH}_{4} \cdot$ ton $^{-1}$ high moisture MSW, respectively, was achieved at an initial loading of $26 \mathrm{gVS} \cdot \mathrm{L}^{-1}$ and $1 \%$ IFA addition. The IFA addition has excellent potential for control during digested high moisture MSW using a two-stage AD process with 87$92 \%$ improvement of biogas production compared to without ash addition. The biogas production from high moisture MSW by two-stage AD has $18.5 \%$ higher energy recovery than a single-stage AD. The coupled incineration with a two-stage biogas production for treating 1-ton of MSW has electricity production of $9,874 \mathrm{MJ}$ with an energy recovery of $89 \%$. Coupled incineration with biogas production via the two-stage AD process is suitable for completely utilizing MSW with low land area requirement, low greenhouse gas emission, and high energy recovery.

\section{Acknowledgments}

The authors would like to thank Nakhon Si Thammarat Municipality and Phuket Municipality, Thailand, for providing the municipal solid waste and incineration fly ash.

\section{References}

Abdeshahian P, Lim JS, Ho WS, Hashim H, Lee CT. 2016. Potential of biogas production from farm animal waste in Malaysia. Renewable and Sustainable Energy Reviews 60:714-723. DOI: https://doi.org/10.1016/j.rser.2016.01.117.

Angelidaki I, Alves M, Bolzonella D, Borzacconi L, Campos JL, Guwy AJ, Kalyuzhnyi S, Jenicek P, Van Lier JB. 2009. Defining the biomethane potential (BMP) of solid organic wastes and energy crops: A proposed protocol for batch assays. Water Science and Technology 59:927-934. DOI: 10.2166/wst.2009.040.

APHA. 2012. Standard Methods for the Examination of Water and Wastewater (22nd Ed.). Washington DC, USA: American Public Health Association.

Armijo de Vega C, Ojeda Benítez S, Ramírez Barreto ME. 2008. Solid waste characterization and recycling potential for a university campus. Waste Management 28:S21-S26. DOI: https://doi.org/10.1016/j.wasman.2008.03.022.

Banks CJ, Lo H-M. 2003. Assessing the effects of municipal solid waste incinerator bottom ash on the decomposition of biodegradable waste using a completely mixed anaerobic reactor. Waste Management \& Research 21:225-234. DOI: 10.1177/0734242X0302100306.

Barampouti EMP, Mai ST, Vlyssides AG. 2005. Dynamic Modeling of the Ratio Volatile Fatty Acids/Bicarbonate Alkalinity in a UASB Reactor for Potato Processing Wastewater Treatment. Environmental Monitoring and Assessment 110:121-128. DOI: 10.1007/s10661005-6282-1.

Borowski S. 2015. Co-digestion of the hydromechanically separated organic fraction of municipal solid waste with sewage sludge. Journal of Environmental Management 147:87-94. DOI: https://doi.org/10.1016/j.jenvman.2014.09.013. 
436 Buswell A. M, Mueller H. F. 1952. Mechanism of methane fermentation. Industrial \& 437 Engineering Chemistry 44:550-552. DOI: https://doi.org/10.1021/ie50507a033

438 Demirel B, Yenigün O. 2002. Two-phase anaerobic digestion processes: a review. Journal of 439 Chemical Technology \& Biotechnology 77:743-755. DOI: 10.1002/jctb.630.

440 Dong L, Zhenhong Y, Yongming S, Xiaoying K, Yu Z. 2009. Hydrogen production 441 characteristics of the organic fraction of municipal solid wastes by anaerobic mixed culture 442 fermentation. International Journal of Hydrogen Energy 34:812-820. DOI: 443 10.1016/j.ijhydene.2008.11.031.19

444 Forster-Carneiro T, Pérez M, Romero LI, Sales D. 2007. Dry-thermophilic anaerobic 445 digestion of organic fraction of the municipal solid waste: Focusing on the inoculum sources. 446 Bioresource Technology 98:3195-3203. DOI: 10.1016/j.biortech.2006.07.008.

447 Jakob A, Stucki S, Kuhn P. 1995. Evaporation of Heavy Metals during the Heat Treatment of 448 Municipal Solid Waste Incinerator Fly Ash. Environmental Science \& Technology 29:2429449 2436. DOI: 10.1021/es00009a040.

450 Khanal S.K., 2008. Anaerobic Biotechnology for Bioenergy Production: Principles and 451 Applications. John \& Wiley Sons Inc., Iowa. DOI: https://doi.org/10.1002/9780813804545.

452 Kuske CR, Banton KL, Adorada DL, Stark PC, Hill KK, Jackson PJ. 1998. Small-Scale 453 DNA Sample Preparation Method for Field PCR Detection of Microbial Cells and Spores in 454 Soil. Applied and Environmental Microbiology 64:2463-2472.

455 Lesteur M, Bellon-Maurel V, Gonzalez C, Latrille E, Roger JM, Junqua G, Steyer JP. 456 2010. Alternative methods for determining anaerobic biodegradability: A review. Process 457 Biochemistry 45:431-440. DOI: https://doi.org/10.1016/j.procbio.2009.11.018.

458 Lo H-M. 2005. Metals behaviors of MSWI bottom ash co-digested Anaerobically with MSW. 459 Resources, Conservation, and Recycling 43:263-280. DOI: 460 https://doi.org/10.1016/j.resconrec.2004.06.004.

461 Luo G, De Francisci D, Kougias PG, Laura T, Zhu X, Angelidaki I. 2015. New steady-state 462 microbial community compositions and process performances in biogas reactors induced by 463 temperature disturbances. Biotechnology for Biofuels 8:3. DOI: 10.1186/s13068-014-0182-y.

464 Mamimin C, Jehlee A, Saelor S, Prasertsan P, O-Thong S. 2016. Thermophilic hydrogen 465 production from co-fermentation of palm oil mill effluent and decanter cake by 466 Thermoanaerobacterium thermosaccharolyticum PSU-2. International Journal of Hydrogen 467 Energy 41:21692-21701. DOI: https://doi.org/10.1016/j.ijhydene.2016.07.152.

468 Mamimin C, Probst M, Gómez-Brandón M, Podmirseg SM, Insam H, Reungsang A, O469 Thong S. 2019. Trace metals supplementation enhanced microbiota and biohythane production 470 by two-stage thermophilic fermentation. International Journal of Hydrogen Energy 44:3325471 3338. DOI: https://doi.org/10.1016/j.ijhydene.2018.09.065.

472 Mamimin C, Singkhala A, Kongjan P, Suraraksa B, Prasertsan P, Imai T, O-Thong S. 473 2015. Two-stage thermophilic fermentation and mesophilic methanogen process for biohythane 474 production from palm oil mill effluent. International Journal of Hydrogen Energy 40:6319-6328. 475 DOI: https://doi.org/10.1016/j.ijhydene.2015.03.068. 
476 Martín-González L, Castro R, Pereira MA, Alves MM, Font X, Vicent T. 2011. 477 Thermophilic co-digestion of organic fraction of municipal solid wastes with FOG wastes from a 478 sewage treatment plant: Reactor performance and microbial community monitoring. Bioresource 479 Technology 102:4734-4741. DOI: https://doi.org/10.1016/j.biortech.2011.01.060.

480 Mattioli A, Gatti GB, Mattuzzi GP, Cecchi F, Bolzonella D. 2017. Co-digestion of the organic 481 fraction of municipal solid waste and sludge improves the energy balance of wastewater 482 treatment plants: Rovereto case study. Renewable Energy 113:980-988. DOI: 483 https://doi.org/10.1016/j.renene.2017.06.079.

484 Michele P, Giuliana D, Carlo M, Sergio S, Fabrizio A. 2015. Optimization of solid-state 485 anaerobic digestion of the OFMSW by digestate recirculation: A new approach. Waste 486 Management 35:111-118. DOI: 10.1016/j.wasman.2014.09.009.

487 Nie Y. 2008. Development and prospects of municipal solid waste (MSW) incineration in China. 488 Frontiers of Environmental Science \& Engineering in China, 2:1-7. DOI: 10.1007/s11783-008489 0028-6.

490 O-Thong S, Prasertsan P, Birkeland N-K. 2009. Evaluation of methods for preparing 491 hydrogen-producing seed inocula under thermophilic condition by process performance and 492 microbial community analysis. Bioresource Technology 100:909-918. DOI: 493 https://doi.org/10.1016/j.biortech.2008.07.036.

494 O-Thong S, Suksong W, Promnuan K, Thipmunee M, Mamimin C, Prasertsan P. 2016. 495 Two-stage thermophilic fermentation and mesophilic methanogenic process for biohythane 496 production from palm oil mill effluent with methanogenic effluent recirculation for $\mathrm{pH}$ control. 497 International Journal of Hydrogen Energy. 41:21702-21712. DOI: 498 https://doi.org/10.1016/j.ijhydene.2016.07.095.

499 Pavi S, Kramer LE, Gomes LP, Miranda LAS. 2017. Biogas production from co-digestion of 500 organic fraction of municipal solid waste and fruit and vegetable waste. Bioresource Technology 501 228:362-367. DOI: https://doi.org/10.1016/j.biortech.2017.01.003.

502 Podmirseg SM, Seewald MSA, Knapp BA, Bouzid O, Biderre-Petit C, Peyret P, Insam H. 503 2013. Wood ash amendment to biogas reactors as an alternative to landfilling? A preliminary 504 study on changes in process chemistry and biology. Waste Management \& Research 31:829505 842. DOI: 10.1177/0734242X13497077.

506 Prasertsan P, O-Thong S, Birkeland NK. 2009. Optimization and microbial community 507 analysis for the production of biohydrogen from palm oil mill effluent by the thermophilic 508 fermentative process. International Journal of Hydrogen Energy 34:7448-7459. DOI: 509 10.1016/j.ijhydene.2009.04.075.

510 Rincón B, Borja R, Martín MA, Martín A. 2009. Evaluation of the methanogenic step of a 511 two-stage anaerobic digestion process of acidified olive mill solid residue from a previous 512 hydrolytic-acidogenic step. Waste Management 29:2566-2573. DOI: 513 https://doi.org/10.1016/j.wasman.2009.04.009. 
514 Sukholthaman P, Sharp A. 2016. A system dynamics model to evaluate the effects of source 515 separation of municipal solid waste management: A case of Bangkok, Thailand. Waste 516 Management 52:50-61. DOI: https://doi.org/10.1016/j.wasman.2016.03.026.

517 Tan J, Liu Z, Bao X, Liu X, Han X, He C, Zhai R. 2002. Crystallization and Si incorporation 518 mechanisms of SAPO-34. Microporous and Mesoporous Materials, 53:97-108. DOI: 519 https://doi.org/10.1016/S1387-1811(02)00329-3.

520 Tatusova T, DiCuccio M, Badretdin A, Chetvernin V, Nawrocki E. P, Zaslavsky L, Ostell 521 J. 2016. NCBI prokaryotic genome annotation pipeline. Nucleic acids research 44: 6614-6624. 522 DOI: https://doi.org/10.1093/nar/gkw569

523 Thanh PM, Ketheesan B, Yan Z, Stuckey D. 2016. Trace metal speciation and bioavailability 524 in anaerobic digestion: A review. Biotechnology Advances 34:122-136. DOI: 525 https://doi.org/10.1016/j.biotechadv.2015.12.006.

526 Yan M, Fotidis I. A, Tian H, Khoshnevisan B, Treu L, Tsapekos P, Angelidaki I. 2019. 527 Acclimatization contributes to stable anaerobic digestion of organic fraction of municipal solid 528 waste under extreme ammonia levels: Focusing on microbial community dynamics. Bioresource 529 technology 286: 121376. DOI: https://doi.org/10.1016/j.biortech.2019.121376

530 Yang L, Xu F, Ge X, Li Y. 2015. Challenges and strategies for solid-state anaerobic digestion 531 of lignocellulosic biomass. Renewable and Sustainable Energy Reviews 44:824-834. DOI: 532 10.1016/j.rser.2015.01.002.

533 Yu J, Qiao Y, Sun L, Jin L, Wang W, Ma C. 2015. Detoxification of ashes from a fluidized 534 bed waste incinerator. Chemosphere

134:346-354. DOI:

535 https://doi.org/10.1016/j.chemosphere.2015.04.045.

536 Yuan X, Cao Y, Li J, Wen B, Zhu W, Wang X, Cui Z. 2012. Effect of pretreatment by a 537 microbial consortium on methane production of waste paper and cardboard. Bioresource 538 Technology 118:281-288. DOI: 10.1016/j.biortech.2012.05.058.

539 Zahedi S, Solera R, Micolucci F, Cavinato C, Bolzonella D. 2016. Changes in microbial 540 community during hydrogen and methane production in two-stage thermophilic anaerobic co541 digestion process from biowaste. Waste Management 49:40-46. DOI: 542 https://doi.org/10.1016/j.wasman.2016.01.016.

543 Zhang X, Qiu W, Chen H. 2012. Enhancing the hydrolysis and acidification of steam-exploded 544 cornstalks by intermittent $\mathrm{pH}$ adjustment with an enriched microbial community. Bioresource 545 Technology 123:30-35. DOI: https://doi.org/10.1016/j.biortech.2012.07.054.

546 Zhang Z, Zhang G, Li W, Li C, Xu G. 2016. Enhanced biogas production from sorghum stem 547 by co-digestion with cow manure. International Journal of Hydrogen Energy 41:9153-9158. 548 DOI: https://doi.org/10.1016/j.ijhydene.2016.02.042.

549 Zhen G. Lu X, Kobayashi T, Kumar G, Xu, K. 2016. Anaerobic co-digestion on improving 550 methane production from mixed microalgae (Scenedesmus sp., Chlorella sp.) and food waste: 551 kinetic modeling and synergistic impact evaluation. Chemical Engineering Journal, 299:332-341. 552 DOI: https://doi.org/10.1016/j.cej.2016.04.118. 


\section{List of figures}

561

562

563

564

565

566

567

568

569

570

571

572

573

574

575

576

577

578

579

Figure 1. Schematic diagram of the one-stage AD process (a) and two-stage AD process (b) for biogas production from high moisture MSW

Figure 2. Cumulative methane yield from single-stage anaerobic digestion of high moisture municipal solid waste with $0.5 \%$ (A) and $1.0 \%$ (B) addition of IFA for $\mathrm{pH}$ adjustment

Figure 3. Cumulative hydrogen and methane yield from two-stage anaerobic digestion of high moisture municipal solid waste with incineration fly ash addition for $\mathrm{pH}$ adjustment at $0.5 \%(\mathrm{~A}-\mathrm{B})$ and $1 \%(\mathrm{C}-\mathrm{D})$

Figure 4. Bacterial community in the first stage (S1-BACT), bacterial community in the second stage (S2-BACT), and archaea community in the second stage (S2-ARCH) of the twostage anaerobic digestion process of high moisture municipal solid waste for hydrogen and methane production at an initial volatile solids loading of $43 \mathrm{~g}-\mathrm{VS} \mathrm{L}^{-1}$ and IFA addition at $1.0 \%$

580

581

582

Figure 5. Energy recovery from municipal solid waste by the coupled incineration process and two-stage anaerobic digestion 
Figure 1

Schematic diagram of the one-stage AD process (a) and two-stage AD process (b) for biogas production from high moisture MSW. 
(a) One-stage reactor
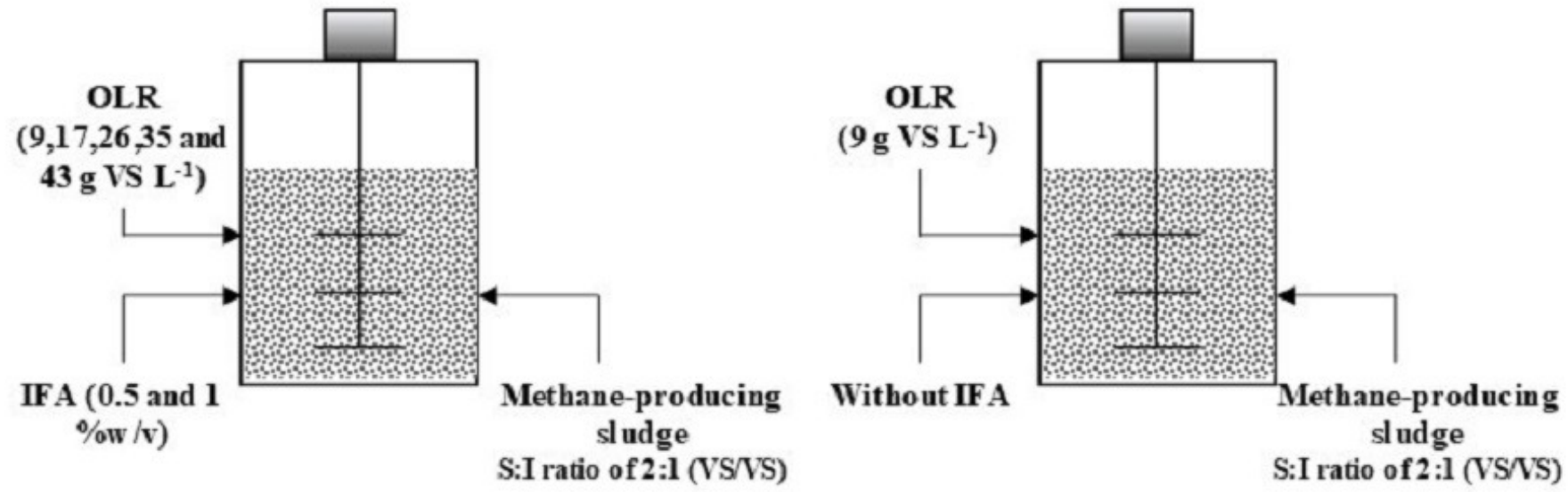

(b) Two-stage reactor
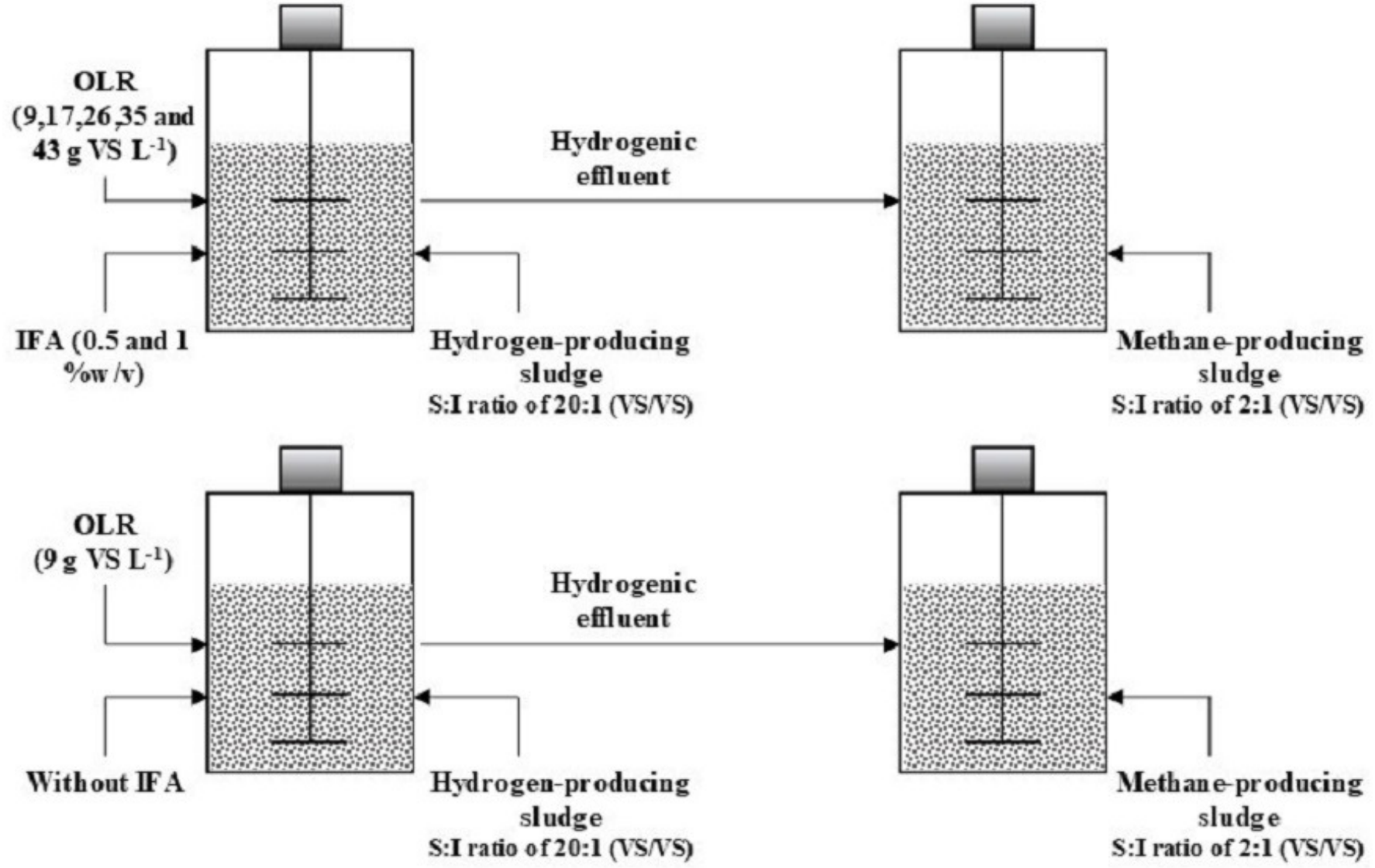
Figure 2

Cumulative methane yield from single-stage anaerobic digestion of high moisture municipal solid waste with $0.5 \%$ (A) and $1.0 \%$ (B) addition of IFA for pH adjustment. 

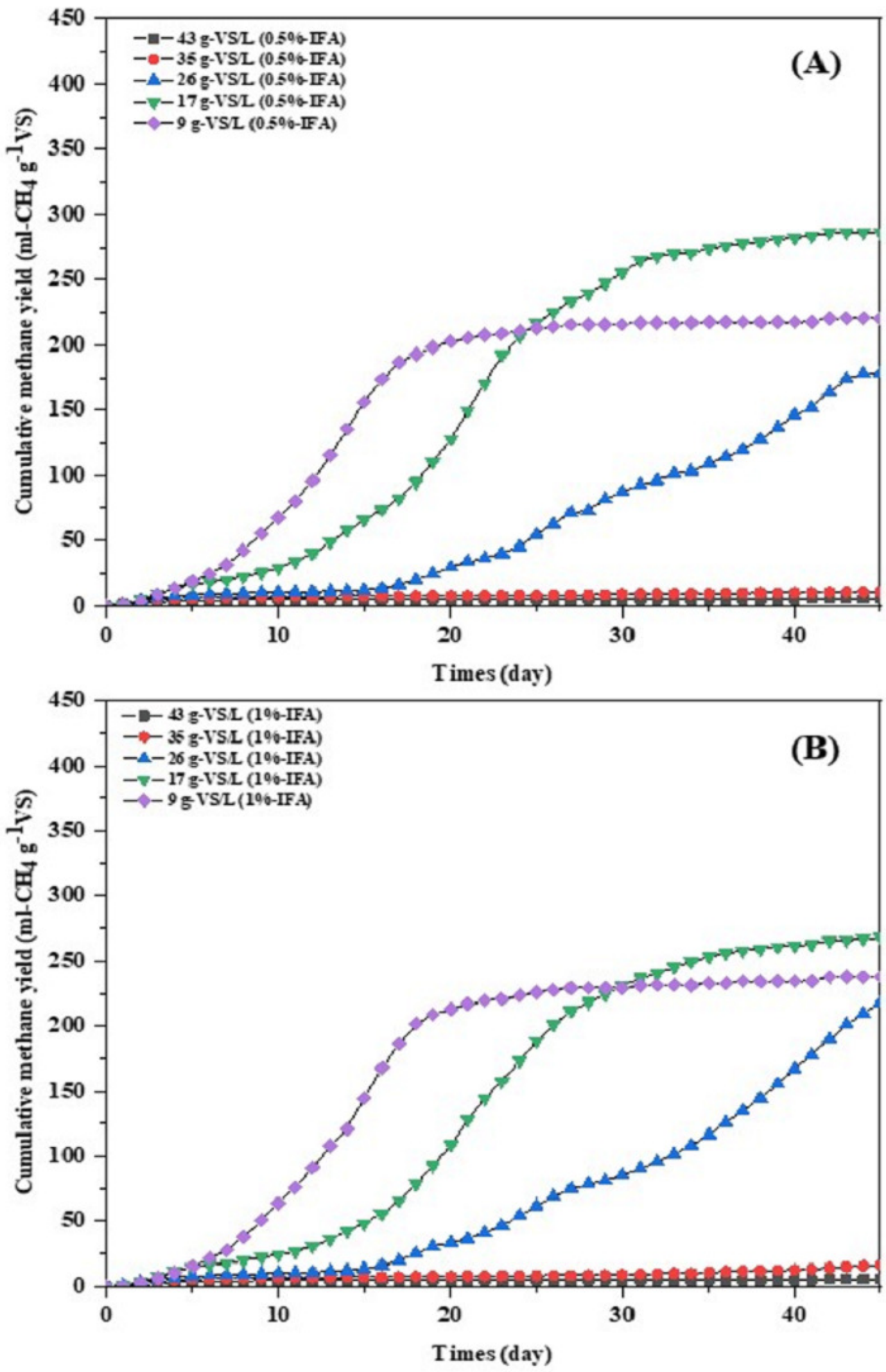
Figure 3

Cumulative hydrogen and methane yield from two-stage anaerobic digestion of high moisture municipal solid waste with incineration fly ash addition for $\mathrm{pH}$ adjustment at $0.5 \%(A-B)$ and $1 \%(C-D)$.
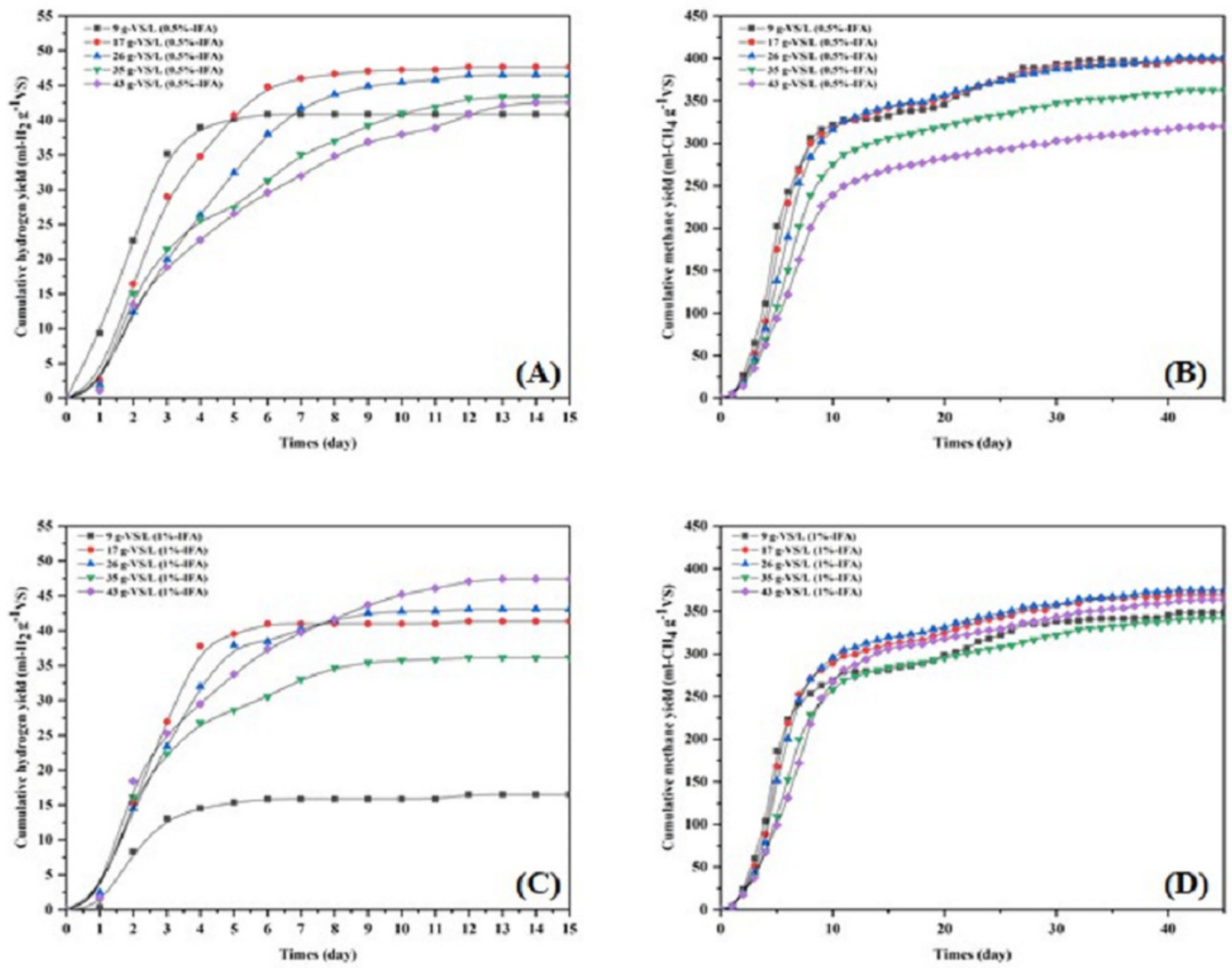


\section{Figure 4}

Bacterial community in the first stage (S1-BACT), bacterial community in the second stage (S2-BACT), and archaea community in the second stage (S2-ARCH) of the twostage anaerobic digestion process of high moisture municipal solid waste for hydrogen and methane production at an initial volatile solids loading of $43 \mathrm{~g}-\mathrm{VS} \mathrm{L}-1$ and IFA addition at $1.0 \%$. 


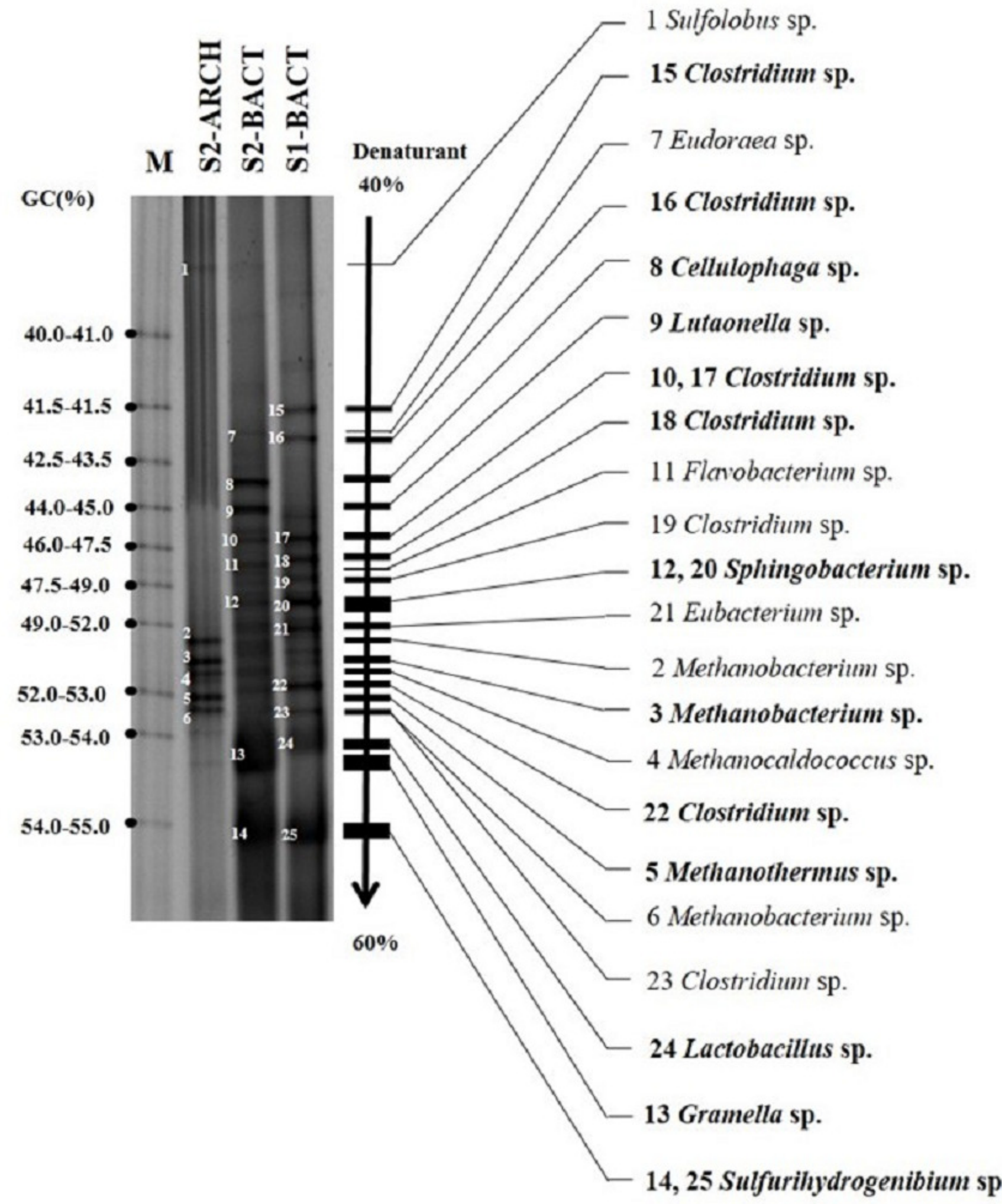


Figure 5

Energy recovery from municipal solid waste by the coupled incineration process and two-stage anaerobic digestion.
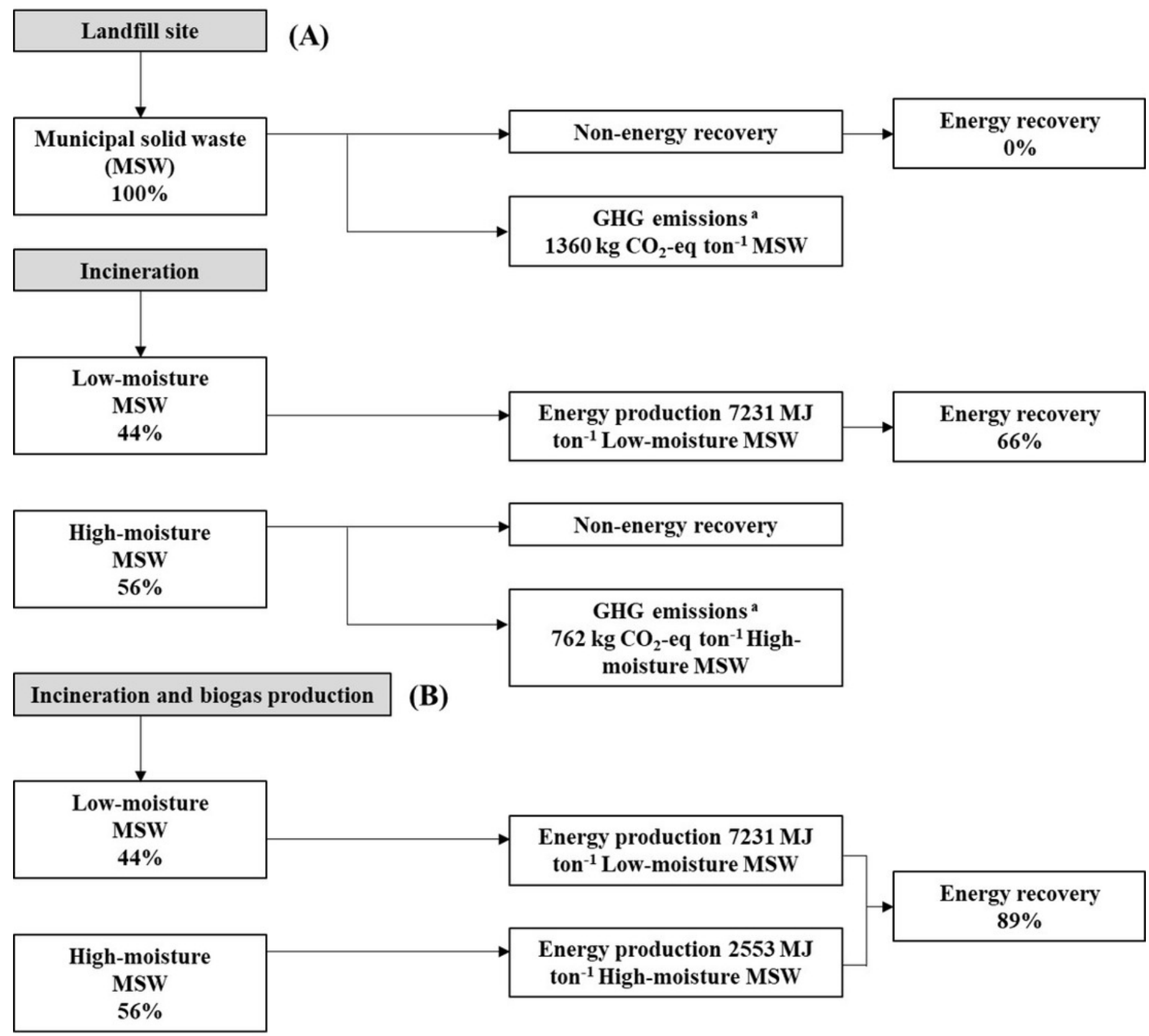


\section{Table 1 (on next page)}

Characteristics of inoculum for hydrogen and methane production. 
1 Table 1. Characteristics of inoculum for hydrogen and methane production.

\begin{tabular}{lcc}
\hline Parameters & Hydrogen producing sludge & Methane producing sludge \\
\hline Total solids (\%) & 2.99 & 9.72 \\
Total volatile solids (\%) & 2.38 & 8.37 \\
$\mathrm{pH}$ & 5.52 & 7.83 \\
Alkalinity $\left(\mathrm{mg}_{-}-\mathrm{CaCO}_{3} \mathrm{~L}\right)$ & 2400 & 5200 \\
\hline
\end{tabular}


Table 2 (on next page)

Characteristics of high moisture municipal solid waste from Nakhon Si Thammarat landfill site, Thailand. 
1 Table 2. Characteristics of high moisture municipal solid waste from Nakhon Si Thammarat

2 landfill site, Thailand

\begin{tabular}{lc}
\hline Parameters & High moisture MSW \\
\hline $\mathrm{pH}$ & 5.6 \\
Total solids (\%w/w) & 26.4 \\
Volatile solids (\%w/w) & 18.3 \\
Ash $(\% \mathrm{w} / \mathrm{w})$ & 8.02 \\
Moisture $(\% \mathrm{w} / \mathrm{w})$ & 73.6 \\
$\mathrm{C}(\%)$ & 51.2 \\
$\mathrm{H}(\%)$ & 66.6 \\
$\mathrm{O}(\%)$ & 40.3 \\
$\mathrm{~N}(\%)$ & 2.0 \\
$\mathrm{~S}(\%)$ & 0.1 \\
Protein $(\%$ of TS) & 20.4 \\
Carbohydrate $(\%$ of TS) & 38.6 \\
Lipid $(\%$ of TS) & 11.0 \\
\hline
\end{tabular}

3 


\section{Table 3 (on next page)}

Composition of incineration fly ash from incineration of high moisture municipal solid waste. 
1 Table 3. Composition of incineration fly ash from incineration of high moisture municipal solid 2 waste.

\begin{tabular}{cc}
\hline Elements & Value $(\%$ of TS) \\
\hline $\mathrm{Na}_{2} \mathrm{O}$ & 8.35 \\
$\mathrm{MgO}$ & 1.17 \\
$\mathrm{Al}_{2} \mathrm{O}$ & 0.663 \\
$\mathrm{SiO}_{2}$ & 1.65 \\
$\mathrm{P}_{2} \mathrm{O}_{5}$ & 0.689 \\
$\mathrm{SO}_{3}$ & 3.22 \\
$\mathrm{Cl}$ & 22.1 \\
$\mathrm{~K}_{2} \mathrm{O}$ & 4.95 \\
$\mathrm{CaO}$ & 39.6 \\
$\mathrm{TiO}_{2}$ & 0.367 \\
$\mathrm{Cr}_{2} \mathrm{O}_{3}$ & 0.014 \\
$\mathrm{MnO}_{\mathrm{Fe}} \mathrm{O}_{3}$ & 0.023 \\
$\mathrm{NiO}$ & 0.432 \\
$\mathrm{CuO}$ & 0.007 \\
$\mathrm{ZnO}$ & 0.055 \\
$\mathrm{Br}$ & 0.427 \\
$\mathrm{Rb}_{2} \mathrm{O}$ & 0.108 \\
$\mathrm{SrO}$ & 0.026 \\
$\mathrm{CdO}$ & 0.050 \\
$\mathrm{SnO}$ & 0.021 \\
$\mathrm{Sb}_{2} \mathrm{O}_{3}$ & 0.048 \\
$\mathrm{PbO}$ & 0.026 \\
\hline
\end{tabular}

3 


\section{Table 4 (on next page)}

Process performance of single-stage anaerobic digestion of high moisture MSW. 
Table 4. Process performance of single-stage anaerobic digestion of high moisture MSW

\begin{tabular}{|c|c|c|c|c|c|c|c|c|c|}
\hline $\begin{array}{c}\text { Initial } \\
\text { VS } \\
\text { loading } \\
\left(\mathrm{g}-\mathrm{VS} \cdot \mathrm{L}^{-}\right. \\
1)\end{array}$ & $\begin{array}{c}\text { IFA } \\
\text { addition } \\
(\% \mathrm{w} / \mathrm{v})\end{array}$ & $\begin{array}{c}\text { Methane } \\
\text { yield (mL } \\
\mathrm{CH}_{4} \cdot \mathrm{g}^{-1} \\
\mathrm{VS})\end{array}$ & $\begin{array}{l}\text { Methane } \\
\text { production } \\
\left(\mathrm{m}^{3}\right. \\
\mathrm{CH}_{4} \cdot \text { ton }^{-1} \\
\mathrm{MSW})\end{array}$ & $\begin{array}{c}\text { Methane } \\
\text { production } \\
\text { rate }(\mathrm{mL} \\
\mathrm{CH}_{4} \cdot \mathrm{g}^{-1} \mathrm{VS} \cdot \mathrm{d}^{-} \\
1)\end{array}$ & $\begin{array}{l}\text { Lag } \\
\text { phase } \\
\text { (d) }\end{array}$ & $\begin{array}{l}\text { Hydrolysis } \\
\text { constant } \\
\left(\mathrm{d}^{-1}\right)\end{array}$ & $\begin{array}{c}\text { VFAs } \\
\left(\mathrm{mg} \cdot \mathrm{L}^{-1}\right)\end{array}$ & $\begin{array}{l}\text { Alkalinity } \\
(\mathrm{mg}- \\
\left.\mathrm{CaCo}_{3} \cdot \mathrm{L}^{-1}\right)\end{array}$ & $\begin{array}{c}\text { Biodegradation } \\
(\%)\end{array}$ \\
\hline 9 & 0.5 & 220 & 37.5 & 18.4 & 6.07 & 0.137 & 209 & 4600 & 38.3 \\
\hline 17 & 0.5 & 287 & 48.7 & 15.3 & 10.6 & 0.108 & 198 & 2600 & 49.8 \\
\hline 26 & 0.5 & 179 & 30.4 & 6.96 & 18.8 & 0.058 & 178 & 3225 & 31.1 \\
\hline 35 & 0.5 & 10.5 & 1.78 & 0.34 & - & 0.063 & 1218 & 2925 & 1.82 \\
\hline 43 & 0.5 & 5.08 & 0.86 & 0.78 & - & 0.089 & 1267 & 3050 & 0.88 \\
\hline 9 & 1 & 238 & 40.4 & 18.9 & 6.66 & 0.128 & 193 & 2450 & 41.2 \\
\hline 17 & 1 & 268 & 45.6 & 14.2 & 11.7 & 0.112 & 224 & 2450 & 46.5 \\
\hline 26 & 1 & 218 & 37.1 & 14.1 & 30.1 & 0.043 & 205 & 2875 & 37.9 \\
\hline 35 & 1 & 16.4 & 2.78 & 5.88 & - & 0.038 & 2240 & 2950 & 2.84 \\
\hline 43 & 1 & 5.35 & 0.91 & 0.69 & - & 0.081 & 2186 & 3500 & 0.93 \\
\hline 9 & 0 & 0 & 0 & 0 & 0 & 0 & 1235 & 508 & 0.30 \\
\hline
\end{tabular}




\section{Table 5 (on next page)}

Volatile fatty acids distribution in single-stage anaerobic digestion effluent of high moisture MSW. 
1 Table 5. Volatile fatty acids distribution in single-stage anaerobic digestion effluent of high moisture MSW.

\begin{tabular}{|c|c|c|c|c|c|c|c|c|}
\hline $\begin{array}{c}\text { Initial VS } \\
\text { loading (g- } \\
\left.\text { VS } \cdot L^{-1}\right)\end{array}$ & $\begin{array}{c}\text { IFA } \\
\text { addition } \\
(\% \mathrm{w} / \mathrm{v})\end{array}$ & $\begin{array}{l}\text { Acetic acid } \\
\left(\mathrm{mg} \cdot \mathrm{L}^{-1}\right)\end{array}$ & $\begin{array}{c}\text { Propionic } \\
\text { acid }\left(\mathrm{mg} \cdot \mathrm{L}^{-1}\right)\end{array}$ & $\begin{array}{c}\text { Isobutyric } \\
\text { acid }\left(\mathrm{mg} \cdot \mathrm{L}^{-1}\right)\end{array}$ & $\begin{array}{l}\text { Butyric acid } \\
\left(\mathrm{mg} \cdot \mathrm{L}^{-1}\right)\end{array}$ & $\begin{array}{c}\text { Isovaleric } \\
\text { acid }\left(\mathrm{mg} \cdot \mathrm{L}^{-1}\right)\end{array}$ & $\begin{array}{c}\text { Valeric } \\
\text { acid } \\
\left(\mathrm{mg} \cdot \mathrm{L}^{-1}\right)\end{array}$ & $\begin{array}{l}\text { TVFAs } \\
\left(\mathrm{mg} \cdot \mathrm{L}^{-1}\right)\end{array}$ \\
\hline 9 & 0.5 & 88.2 & 13.9 & 4.4 & 99.1 & 3.4 & 0 & 209 \\
\hline 17 & 0.5 & 85.4 & 13.4 & 3.4 & 92.9 & 3.0 & 0 & 198 \\
\hline 26 & 0.5 & 76.1 & 11.6 & 2.9 & 84.8 & 2.7 & 0 & 178 \\
\hline 35 & 0.5 & 531.8 & 78.1 & 18.7 & 571.3 & 18.0 & 0 & 1218 \\
\hline 43 & 0.5 & 535.5 & 115.3 & 22.6 & 574.3 & 19.2 & 0 & 1267 \\
\hline 9 & 1 & 85.3 & 11.8 & 3.0 & 89.8 & 3.1 & 0 & 193 \\
\hline 17 & 1 & 97.3 & 13.8 & 3.8 & 105.3 & 3.7 & 0 & 224 \\
\hline 26 & 1 & 89.7 & 11.8 & 3.1 & 97.3 & 3.0 & 0 & 205 \\
\hline 35 & 1 & 972.2 & 143.5 & 35.0 & 1028.1 & 38.1 & 23.1 & 2240 \\
\hline 43 & 1 & 979.5 & 187.2 & 30.7 & 958.6 & 30.1 & 0 & 2186 \\
\hline 9 & 0 & 553.4 & 105.7 & 17.3 & 541.6 & 17.0 & 0 & 1235 \\
\hline
\end{tabular}




\section{Table 6(on next page)}

Process performance of two-stage anaerobic digestion of high moisture municipal solid waste (MSW) from Nakhon Si Thammarat landfill site, Thailand. 
Table 6 Process performance of two-stage anaerobic digestion of high moisture municipal solid waste (MSW) from Nakhon Si Thammarat landfill site, Thailand

\begin{tabular}{|c|c|c|c|c|c|c|c|c|c|}
\hline \multicolumn{10}{|c|}{ Hydrogen production stage } \\
\hline $\begin{array}{l}\text { Initial VS } \\
\text { loading (g- } \\
\left.\text { VS } \cdot L^{-1}\right)\end{array}$ & $\begin{array}{c}\text { IFA } \\
\text { additio } \\
\mathrm{n}(\%)\end{array}$ & $\begin{array}{l}\text { Hydrogen } \\
\text { yield (mL } \\
\left.\mathrm{H}_{2} \cdot \mathrm{g}^{-1} \mathrm{VS}\right)\end{array}$ & $\begin{array}{c}\text { Hydrogen } \\
\text { production }\left(\mathrm{m}^{3}\right. \\
\left.\mathrm{H}_{2} \cdot \text { tonne }^{-1} \mathrm{MSW}\right)\end{array}$ & $\begin{array}{c}\text { Hydrogen } \\
\text { production rate }(\mathrm{mL} \\
\left.\mathrm{H}_{2} \cdot \mathrm{g}^{-1} \mathrm{VS} \cdot \mathrm{d}^{-1}\right)\end{array}$ & $\begin{array}{l}\text { Lag } \\
\text { phase } \\
\text { (d) }\end{array}$ & $\begin{array}{l}\text { Hydroly } \\
\text { sis } \\
\text { constant } \\
\left(\mathrm{d}^{-1}\right) \\
\end{array}$ & $\begin{array}{l}\text { VFAs } \\
\left(\mathrm{mg} \cdot \mathrm{L}^{-}\right. \\
\text {1) }\end{array}$ & $\begin{array}{l}\text { Alkalinity } \\
\left(\mathrm{mg}_{-}\right. \\
\left.\mathrm{CaCO}_{3} \cdot \mathrm{L}^{-1}\right)\end{array}$ & $\begin{array}{l}\text { Biodegra } \\
\text { dation } \\
(\%)\end{array}$ \\
\hline 9 & 0.5 & 40.8 & 6.94 & 16.20 & 0.48 & 0.871 & 1607 & 1050 & 9.1 \\
\hline 17 & 0.5 & 47.6 & 8.10 & 12.70 & 0.79 & 0.502 & 1185 & 900 & 10.6 \\
\hline 26 & 0.5 & 46.4 & 7.90 & 8.58 & 0.78 & 0.412 & 1706 & 925 & 10.3 \\
\hline 35 & 0.5 & 43.3 & 7.36 & 6.33 & 0.14 & 0.301 & 1771 & 1087 & 9.6 \\
\hline 43 & 0.5 & 42.5 & 7.23 & 5.65 & 0.14 & 0.229 & 2066 & 1062 & 9.4 \\
\hline 9 & 1 & 16.4 & 2.80 & 7.96 & 1.02 & 0.331 & 1350 & 950 & 3.6 \\
\hline 17 & 1 & 41.3 & 7.03 & 15.88 & 1.08 & 0.522 & 1195 & 987 & 9.2 \\
\hline 26 & 1 & 43.0 & 7.32 & 11.03 & 0.81 & 0.504 & 1423 & 1050 & 9.6 \\
\hline 35 & 1 & 36.1 & 6.14 & 8.45 & 0.47 & 0.463 & 2020 & 1300 & 8.0 \\
\hline 43 & 1 & 47.4 & 8.06 & 8.11 & 0.24 & 0.358 & 1680 & 1075 & 10.5 \\
\hline 9 & 0 & 8.05 & 1.39 & 1.61 & 0.68 & 0.348 & 3328 & 315 & 1.8 \\
\hline \multicolumn{10}{|c|}{ Methane production stage } \\
\hline $\begin{array}{l}\text { Initial VS } \\
\text { loading (g- } \\
\left.\text { VS } \cdot L^{-1}\right)\end{array}$ & $\begin{array}{c}\text { IFA } \\
\text { additio } \\
\mathrm{n}(\%)\end{array}$ & $\begin{array}{l}\text { Methane yield } \\
\left(\mathrm{mL} \mathrm{CH}_{4} \cdot \mathrm{g}^{-}\right. \\
\left.{ }^{1} \mathrm{VS}\right)\end{array}$ & $\begin{array}{c}\text { Methane production } \\
\left(\mathrm{m}^{3} \mathrm{CH}_{4} \cdot \text { tonne } \mathrm{e}^{-1}\right. \\
\mathrm{MSW})\end{array}$ & $\begin{array}{l}\text { Methane production } \\
\text { rate }\left(\mathrm{mL} \mathrm{CH}_{4} \cdot \mathrm{g}^{-1} \mathrm{VS}\right. \\
\left.\mathrm{d}^{-1}\right)\end{array}$ & $\begin{array}{l}\text { Lag } \\
\text { phase } \\
\text { (d) }\end{array}$ & $\begin{array}{l}\text { Hydroly } \\
\text { sis } \\
\text { constant } \\
\left(\mathrm{d}^{-1}\right) \\
\end{array}$ & $\begin{array}{l}\text { VFAs } \\
\left(\mathrm{mg} \cdot \mathrm{L}^{-}\right. \\
1)\end{array}$ & $\begin{array}{l}\text { Alkalinity } \\
\left(\mathrm{mg}_{-}\right. \\
\left.\mathrm{CaCO}_{3} \cdot \mathrm{L}^{-1}\right)\end{array}$ & $\begin{array}{c}\text { Biodegra } \\
\text { dation } \\
(\%)\end{array}$ \\
\hline 9 & 0.5 & 399 & 67.9 & 46.20 & 1.24 & 0.133 & 276 & 3050 & 69.3 \\
\hline 17 & 0.5 & 396 & 67.4 & 47.30 & 1.61 & 0.129 & 152 & 3500 & 68.9 \\
\hline 26 & 0.5 & 400 & 68.1 & 45.10 & 1.86 & 0.113 & 171 & 3450 & 69.6 \\
\hline 35 & 0.5 & 362 & 61.6 & 36.40 & 1.83 & 0.106 & 183 & 3600 & 62.9 \\
\hline 43 & 0.5 & 319 & 54.2 & 30.70 & 1.85 & 0.101 & 78 & 3175 & 55.5 \\
\hline 9 & 1 & 348 & 59.3 & 36.70 & 0.85 & 0.106 & 162 & 3075 & 60.5 \\
\hline 17 & 1 & 369 & 62.2 & 41.40 & 1.37 & 0.121 & 197 & 3400 & 64.1 \\
\hline 26 & 1 & 375 & 63.8 & 42.90 & 1.71 & 0.114 & 184 & 3525 & 65.1 \\
\hline
\end{tabular}




\begin{tabular}{cccccccccc}
\hline 35 & 1 & 341 & 58.1 & 33.60 & 1.61 & 0.103 & 207 & 3700 & 59.3 \\
43 & 1 & 363 & 61.8 & 33.70 & 1.91 & 0.103 & 176 & 3300 & 63.1 \\
9 & 0 & 315 & 52.8 & 27.73 & 0.952 & 0.104 & 247 & 3100 & 54.8 \\
\hline
\end{tabular}




\section{Table 7 (on next page)}

Volatile fatty acids profile of two-stage anaerobic digestion of high moisture municipal solid waste (MSW) from Nakhon Si Thammarat landfill site, Thailand. 


\begin{tabular}{|c|c|c|c|c|c|c|c|c|}
\hline \multicolumn{9}{|c|}{ Hydrogen production stage } \\
\hline $\begin{array}{l}\text { Initial VS loading } \\
\left(\mathrm{g}-\mathrm{VS} \mathrm{L} \mathrm{L}^{-1}\right)\end{array}$ & $\begin{array}{l}\text { IFA addition } \\
(\% \mathrm{w} / \mathrm{v})\end{array}$ & $\begin{array}{l}\text { Acetic acid } \\
\left(\mathrm{mg} \mathrm{L}^{-1}\right)\end{array}$ & $\begin{array}{l}\text { Propionic acid } \\
\left(\mathrm{mg} \mathrm{L}^{-1}\right)\end{array}$ & $\begin{array}{l}\text { Isobutyric acid } \\
\left(\mathrm{mg} \mathrm{L}^{-1}\right)\end{array}$ & $\begin{array}{c}\text { Butyric acid } \\
\left(\mathrm{mg} \mathrm{L}^{-1}\right)\end{array}$ & $\begin{array}{l}\text { Isovaleric acid } \\
\left(\mathrm{mg} \mathrm{L}^{-1}\right)\end{array}$ & $\begin{array}{c}\text { Valeric acid } \\
\left(\mathrm{mg} \mathrm{L}^{-1}\right)\end{array}$ & $\begin{array}{l}\text { TVFAs } \\
\left(\mathrm{mg} \mathrm{L}^{-1}\right)\end{array}$ \\
\hline 9 & 0.5 & 678.1 & 156.2 & 24.4 & 721.5 & 26.9 & 0.0 & 1607 \\
\hline 17 & 0.5 & 454.0 & 153.2 & 0.0 & 559.4 & 18.4 & 0.0 & 1185 \\
\hline 26 & 0.5 & 766.8 & 102.0 & 25.0 & 786.6 & 25.6 & 0.0 & 1706 \\
\hline 35 & 0.5 & 732.1 & 239.0 & 0.0 & 776.6 & 23.3 & 0.0 & 1771 \\
\hline 43 & 0.5 & 805.8 & 336.4 & 29.3 & 866.1 & 28.4 & 0.0 & 2066 \\
\hline 9 & 1 & 508.7 & 161.1 & 20.0 & 635.7 & 24.5 & 0.0 & 1350 \\
\hline 17 & 1 & 493.6 & 157.6 & 0.0 & 522.2 & 21.6 & 0.0 & 1195 \\
\hline 26 & 1 & 503.7 & 242.0 & 0.0 & 657.4 & 19.9 & 0.0 & 1423 \\
\hline 35 & 1 & 689.1 & 377.6 & 37.1 & 863.3 & 25.8 & 27.2 & 2020 \\
\hline 43 & 1 & 682.3 & 267.8 & 19.7 & 685.9 & 24.3 & 0.0 & 1680 \\
\hline 9 & 0 & 1351.5 & 530.5 & 39.1 & 1358.7 & 48.1 & 0.0 & 3328 \\
\hline \multicolumn{9}{|c|}{ Methane production stage } \\
\hline $\begin{array}{c}\text { Initial VS loading } \\
\left(\mathrm{g}-\mathrm{VS} \mathrm{L}^{-1}\right)\end{array}$ & $\begin{array}{c}\text { IFA addition } \\
(\% \mathrm{w} / \mathrm{v})\end{array}$ & $\begin{array}{c}\text { Acetic acid } \\
\left(\mathrm{mg} \mathrm{L}^{-1}\right)\end{array}$ & $\begin{array}{l}\text { Propionic acid } \\
\left(\mathrm{mg} \mathrm{L}^{-1}\right)\end{array}$ & $\begin{array}{c}\text { Isobutyric acid } \\
\left(\mathrm{mg} \mathrm{L}^{-1}\right)\end{array}$ & $\begin{array}{c}\text { Butyric acid } \\
\left(\mathrm{mg} \mathrm{L}^{-1}\right)\end{array}$ & $\begin{array}{c}\text { Isovaleric acid } \\
\left(\mathrm{mg} \mathrm{L}^{-1}\right)\end{array}$ & $\begin{array}{c}\text { Valeric acid } \\
\left(\mathrm{mg} \mathrm{L}^{-1}\right)\end{array}$ & $\begin{array}{l}\text { TVFAs } \\
\left(\mathrm{mg} \mathrm{L}^{-1}\right)\end{array}$ \\
\hline 9 & 0.5 & 88.95 & 12.80 & 3.12 & 88.37 & 82.47 & 0.00 & 276 \\
\hline 17 & 0.5 & 66.82 & 9.71 & 2.25 & 71.30 & 2.38 & 0.00 & 152 \\
\hline 26 & 0.5 & 76.66 & 10.20 & 2.50 & 78.64 & 2.56 & 0.00 & 171 \\
\hline 35 & 0.5 & 82.04 & 10.81 & 2.43 & 85.34 & 2.84 & 0.00 & 183 \\
\hline 43 & 0.5 & 64.42 & 7.93 & 0.00 & 5.77 & 0.18 & 0.00 & 78 \\
\hline 9 & 1 & 72.27 & 9.64 & 2.40 & 75.62 & 2.40 & 0.00 & 162 \\
\hline 17 & 1 & 83.72 & 12.67 & 3.11 & 94.44 & 3.21 & 0.00 & 197 \\
\hline 26 & 1 & 79.26 & 11.79 & 2.54 & 87.60 & 2.93 & 0.00 & 184 \\
\hline 35 & 1 & 91.29 & 12.32 & 3.11 & 97.38 & 3.10 & 0.00 & 207 \\
\hline 43 & 1 & 79.41 & 11.20 & 2.43 & 80.11 & 2.55 & 0.00 & 176 \\
\hline 9 & 0 & 108.82 & 14.68 & 3.71 & 116.09 & 3.70 & 0.00 & 247 \\
\hline
\end{tabular}


1 Table 7 Volatile fatty acids profile of two-stage anaerobic digestion of high moisture municipal solid waste (MSW) from Nakhon Si

2 Thammarat landfill site, Thailand 